\title{
The Great Inflation and Early Disinflation in Japan and Germany*
}

\author{
Edward Nelson \\ Federal Reserve Bank of St. Louis
}

\begin{abstract}
This paper considers the Great Inflation of the 1970s in Japan and Germany. From 1975 onward, these countries had low inflation relative to other large economies. Traditionally, this success is attributed to stronger discipline on the part of Japan and Germany's monetary authorities - e.g., more willingness to accept temporary unemployment, or greater determination not to monetize government deficits. I instead attribute the success of these countries from the mid-1970s to their governments' and monetary authorities' acceptance that inflation is a monetary phenomenon. Likewise, their higher inflation in the first half of the 1970s is attributable to the fact that their policymakers over this period embraced nonmonetary theories of inflation.
\end{abstract}

JEL Codes: E52, E58, E64, E65.

\section{Introduction}

This paper considers the Great Inflation of the 1970s in Japan and the Federal Republic of Germany. These countries are notable for the fact that their peaks in inflation came earlier in the decade - in 1974 - than in many other countries, while their inflation rates in

\footnotetext{
*I am indebted to the editor, an anonymous referee, and Otmar Issing for comments; to Christina Gerberding, Heinz Herrmann, Johannes Hoffmann, Andreas Worms, and the staff of the Deutsche Bundesbank Fachbibliothek for help in obtaining material on Germany; and to Takushi Kurozumi, Michael Nelson, Katrina Stierholz, and Julia Williams for help with other material. Justin Hauke and Faith Weller provided research assistance. The views expressed in this paper are those of the author and should not be interpreted as those of the Federal Reserve Bank of St. Louis, the Federal Reserve System, or the Board of Governors of the Federal Reserve System. Author contact: Research Division, Federal Reserve Bank of St. Louis, P.O. Box 442, St. Louis, MO 63166. Tel: (314) 444-8712. E-mail: Edward.Nelson@stls.frb.org.
} 
the late 1970s and early 1980s were well below those prevailing elsewhere. A comprehensive explanation for the policy behavior underlying the Great Inflation needs to account for the experiences of these two countries. I argue that the monetary-policy-neglect hypothesis, previously applied to countries with poorer inflation records, can account for behavior in Japan and Germany too.

It has become a cliché to attribute Germany's success in achieving price stability to greater understanding on the part of German policymakers and the German population of the costs of inflation (with this, of course, frequently said to be the legacy of its hyperinflations), and similar observations were made about Japan after it joined the low-inflation league. But the discussion in this paper will move away from this kind of explanation for success. Germany's policymakers certainly stressed the costs to society of even moderate inflation. But such stress was not something that distinguished Germany from elsewhere; e.g., in the United States, Arthur Burns, Chairman of the Board of Governors of the Federal Reserve System, made many apocalyptic statements about the effects of inflation. Nor is it even clear that Germany's policymakers exhibited a relatively greater willingness to accept the costs of disinflation. Indeed, those who believe that the differences between Germany's inflation performance and that of other countries are attributable to different policymaker preferences may be surprised to find that Helmut Schmidt, Germany's Finance Minister and then Federal Chancellor over much of the $1970 \mathrm{~s},{ }^{1}$ stated that "we in the Federal Republic can in any case tolerate 5\% inflation more than 5\% unemployment" (SZ, December 21, 1972, a.t.). ${ }^{2}$ While Schmidt clarified that this claim was "a political value judgment" and did not reflect a belief that such a choice existed, ${ }^{3}$ his statement

\footnotetext{
${ }^{1}$ Despite the Bundesbank's independence, it is appropriate to include the executive branch among the key decisionmakers on monetary policy matters in Germany in the 1970s. The Bundesbank described its 1974 policy changes as "part of a joint strategy agreed with the Federal Government" (BBAR, April 1975, p. 1), and the executive branch was the senior partner on key issues such as exchange rate policy.

${ }^{2}$ The abbreviation "a.t." denotes the present author's translation of German material. Appendix 1 provides acronyms for periodicals cited in the text, while appendix 2 gives bibliographic details for specific articles.

${ }^{3}$ Consistent with this, I show below that Germany's policymakers did not subscribe to Phillips-curve trade-off analysis.
} 
puts in perspective the idea that Germany's success emerged from an especially "hawkish" attitude to inflation compared with other countries.

The belief in policy circles that inflation is very costly to the economy and, therefore, to society does not distinguish Germany and Japan in the 1970s from countries like the United States and the United Kingdom. Rather, the resistance to nonmonetary views of inflation is what makes these countries unusual. As we will see, these views had only a brief heyday in each country (roughly 197172 in both cases) and even then, there was successful resistance to the idea of imposing national wage and price controls.

This distinguishing feature is consistent with the monetarypolicy-neglect hypothesis. The message of that hypothesis is that high inflation is the outcome of episodes during which policymakers attributed inflation to nonmonetary factors, delegating inflation control to nonmonetary devices (such as wage and price controls). Disinflations and low-inflation periods typically follow policymakers' acceptance of the monetary view of inflation and their resulting adjustment of monetary policy. By extensive analysis of statements by policymakers and of key economic commentary during the 1970s, I show that Japan and Germany's inflation-disinflation pattern fits this story.

The experiences of Germany and Japan are natural to study jointly. In the pre-inflation-targeting era, Japan's monetary policy, alongside Germany's, was regarded as an international benchmark. This perspective on Japan's record was reflected in the title of a 1981 paper by a senior Bank of Japan official, "Why Is the Performance of the Japanese Economy So Much Better?," ${ }^{4}$ and Taylor's $(1993,5)$ observation that "Japanese monetary policy did deliver a low inflation rate much earlier than the other countries, and apparently was doing something 'right.'" Over this period, Japan was Milton Friedman's favorite example of successful monetary policy (see, e.g., Friedman 1983, 1990; and NW, September 4, 1978). I argue that the key factor behind this achievement was that Japan's emphasis on nonmonetary means of fighting inflation was brief and over by 1973 .

\footnotetext{
${ }^{4}$ Suzuki (1981).
} 
My emphasis on the doctrines guiding policy, and my specific focus on the 1970s, complements the study of U.S. policy by Romer and Romer (2002) and also distinguishes my study from most existing work on Germany and Japan. While there are many studies of Bundesbank monetary policy, relatively few contributions cover the major years of Germany's period of inflation. Clarida and Gertler (1997) only briefly consider the period before 1978; indeed, the earliest statement by the Bundesbank that they consider is from 1989. Bernanke and Mihov $(1997,1026)$ explicitly limit their coverage to that following "the inception of the current regime," dated as the beginning of 1975. Similarly, Issing (2005) focuses mainly on post1977 policy developments, which accounts for his characterization of Germany as not having experienced the Great Inflation.

Von Hagen (1999a) does cover the leadup to monetary targeting, but his discussion concentrates on the conflicts between fiscal and monetary policy, and does not consider the debate over monetary versus nonmonetary views of inflation, which had largely been resolved by the time monetary targeting was adopted. By contrast, I study Germany's Great Inflation and its disinflation, much of which preceded 1975, with emphasis on the conflict between monetary and nonmonetary perspectives on inflation control. This emphasis brings out an element of Germany's experience highlighted by the Bundesbank in 1980 when it noted that high inflation had arisen during a period of "underestimation of monetary policy as an economic policy instrument." 5

Turning to Japan, there are antecedents to my analysis in the form of the aforementioned Friedman discussions, as well as Hetzel (1999). Friedman (in $N W$, September 4, 1978) discusses Japan's "fundamental change in monetary policy" in 1973, which amounted to an acceptance that "[s] ubstantial inflation is a monetary phenomenon." Hetzel studies Japan's postwar monetary policy and makes the important observation that Japan's 1970s disinflation produced a "profound change in professional and popular views" $(1999,7)$, discarding nonmonetary views of inflation, a conclusion supported by the analysis provided here. But neither Friedman nor Hetzel provides specific documentation of these changes in views. The discussion in

\footnotetext{
${ }^{5}$ Deutsche Bundesbank (1980, 291).
} 
this paper fills this gap by drawing on coverage of inflation in Japan in several newspapers during the 1970s.

In addition, while both Friedman and Hetzel emphasize that a floating exchange rate enabled Japan to disinflate, they do not discuss why Japan chose disinflation when other countries, such as the United Kingdom, initially chose monetary expansion after floating their exchange rate. I provide an answer by studying developments in Japanese macroeconomic debates. Furthermore, the only policymaking agency Hetzel discusses is the Bank of Japan. This is problematic in studying the 1970s, because (i) the Bank of Japan was not independent over this period, so senior members of the Japanese government were key makers of monetary policy, ${ }^{6}$ and (ii) when nonmonetary views of inflation guide policymakers, some of the major policy mistakes will take the form of attempting nonmonetary strategies against inflation. My focus on a wider range of policymakers and policy agencies overcomes this limitation.

The analysis here also sheds light on the merits of accounts of Japan and Germany's success that emphasize nonmonetary factors. There is wide acceptance among monetary economists that differences in monetary policy account for different countries' inflation experiences during the 1970s. Nevertheless, adherents to nonmonetary views of inflation have offered their own rationalizations for the price stability observed in Germany and Japan. For example, in 1977 Denis Healey, the UK Chancellor of the Exchequer, said, "If you talk to West German Chancellor Helmut Schmidt about his country's successes, he will say that the moderation of the unions in Germany, in limiting their wage demands, is largely due to the political relationship established between the Government and the unions" (SUN, March 9, 1977). Walter Heller, former chairman of the Council of Economic Advisers, testified to a U.S. Senate committee in 1979 that Germany's low inflation reflected the fact that Germans were 'benefiting from what they call their 'Concerted Action,' from a kind of social contract or compact between business and government and labor." ${ }^{7}$ Similarly, Braun $(1986,240)$ claims that the

\footnotetext{
${ }^{6}$ Friedman $(N W$, September 4, 1978) acknowledges the Finance Minister's role in producing the 1973 change in monetary policy.

${ }^{7}$ Walter Heller, in his March 5, 1979, testimony to the U.S. Senate Budget Committee $(1979,47)$.
} 
"Concerted Action" incomes policy in Germany "proved to be useful in promoting wage moderation in 1973-75," while a former U.S. ambassador to Germany asserted that moderate union behavior in German wage negotiations "lowered cost-push [pressures] and was certainly an important reason for the relatively favorable inflation rate." 8 Discussions of "Japan Inc." during the 1970s adopted an analogous line of argument for Japan, and in this spirit a Tokyo economics columnist observed in 1978, "Much of Japan's success in fighting rampant inflation has been ascribed ... particularly to the Japanese version of an 'incomes policy' designed to restrain wage increases" ( $J T$, October 16, 1978). I provide evidence on whether these frequently cited features of German and Japanese economic policy made any material contribution to fighting inflation.

This paper proceeds as follows. Section 2 discusses the monetarypolicy-neglect hypothesis. Section 3 discusses the methodology that I use to study policymaking in Japan and Germany. Section 4 covers Japan, and section 5 turns to Germany. Section 6 relates the two countries' experiences to "trade-off exploitation" explanations for the Great Inflation. Section 7 concludes.

\section{The Monetary-Policy-Neglect Hypothesis}

Consider an expectational Phillips curve in generic form:

$$
\pi_{t}=\pi^{e}+\alpha\left(y_{t}-y_{t}^{*}\right)+u_{t},
$$

where $\pi_{t}$ is quarterly inflation, $\pi^{e}$ is expected inflation, $y_{t}-y_{t}^{*}$ is the output gap, and $u_{t}$ is a shift factor (a cost-push shock). Written in terms of equation (1), the Phillips curve delivers special cases such as a traditional shift-adjusted expectational Phillips curve (as in, e.g., Humphrey 1985), where $\pi^{e}$ is $\mathrm{E}_{t-1} \pi_{t}$, or the New Keynesian Phillips curve augmented by a cost-push shock - used by Clarida, Galí, and Gertler (1999) — where $\pi^{e}$ corresponds to expected future inflation $\mathrm{E}_{t} \pi_{t+1}$. The latter version of the Phillips curve allows the $u_{t}$ shock to be serially correlated. ${ }^{9}$ It is clear that if $u_{t}$ is serially correlated, it matters for both inflation and expected future inflation,

\footnotetext{
${ }^{8}$ Hillenbrand (1983, 25, 27).

${ }^{9}$ In the traditional Phillips curve corresponding to $\pi^{e}=\mathrm{E}_{t-1} \pi_{t}$, a serially correlated $u_{t}$ cannot be contemplated in general.
} 
and becomes the sole determinant of these two series if $\alpha=0$. If we consider the New Keynesian Phillips curve further and generalize to allow for a constant term, as well as the usual $\beta<1$ coefficient on expected inflation, it can be shown that the expression for expected future inflation is

$$
\mathrm{E}_{t} \pi_{t+1}=K+\alpha \mathrm{E}_{t} \Sigma_{i=0}^{\infty} \beta^{i}\left(y_{t+i+1}-y_{t+i+1}^{*}\right)+\left(1-\beta \rho_{u}\right)^{-1} \rho_{u} \hat{u}_{t},
$$

where $K$ is a constant, $\rho_{u}$ is the $\operatorname{AR}(1)$ coefficient for the exogenous $u_{t}$ series, and $\hat{u}_{t}$ is the deviation of $u_{t}$ from its mean.

Nonmonetary and monetary views of inflation deliver rival sets of restrictions on equation (2). The monetary view asserts that $\rho_{u}=0$ (implying that $\hat{u}_{t}$ does not matter for expected future inflation), that $\mathrm{E}\left[u_{t+k}\right]=0$ for all $k$ (and so expectations of $u$ do not matter for the constant term $K$ ), and that $\alpha>0$ whatever the value taken by the output gap. The monetary view of inflation thus attributes the 1970s inflation to excess demand and gives cost-push shocks no role other than as one-time price-level shocks (which, for a given expected path of the output gap, matter for current inflation but not expected future inflation).

The nonmonetary view of inflation, by contrast, contends that $\mathrm{E}\left[u_{t+k}\right]$ is generally nonzero and that high inflation reflects high current and prospective values of $u_{t}$; that $\rho_{u}>0$; and that $\alpha=0$ when the output-gap sum in equation (2) is negative. The nonmonetary view of inflation thus attributes the 1970s inflation to costpush shocks and implies that creating negative output gaps does not remove inflationary pressure.

The monetary-policy-neglect hypothesis states that the monetary view of inflation is the correct one and that high-inflation episodes during the 1970s were the result of policymakers' embrace of the nonmonetary view of inflation. This hypothesis has previously been applied to countries whose inflation rates were generally high throughout the $1970 \mathrm{~s},{ }^{10}$ but it has implications for low-inflation experiences too. According to this hypothesis, countries that experienced relatively low inflation, such as Japan and Germany from 1975 onward, did so because their policymakers converted early to a monetary view of inflation. The remainder of this paper documents the

\footnotetext{
${ }^{10}$ Nelson (2005) provides evidence supporting the hypothesis for the United States and the United Kingdom.
} 
case for the monetary-policy-neglect hypothesis as a description of these two countries' experiences, as well as pointing out weaknesses of alternative hypotheses.

\section{Methodology}

My procedure in this paper is to draw on public statements by key policymakers, using these statements to deduce their implied model of inflation. Newspaper reports are used as a major source for policymaker statements. This methodology raises two major questions: (i) How reliable are the public statements as an indicator of policymakers' true views about the economy? (ii) How representative are the statements that I present-i.e., are my findings insulated from selection bias? I consider each of these issues in turn.

How reliable are the statements? An objection that could be raised about my reliance on public statements for deducing policymaker beliefs is that policymakers give different views publicly from those they express privately. This objection is, however, unlikely to be valid for the type of policymaker views I consider, which pertain to how the structure of the economy behaves over periods of a quarter or more. Policymakers have no plausible incentive to be secretive about matters like this. They certainly may not be forthcoming on specific day-to-day considerations about policy tactics, such as the timing of forthcoming interest-rate decisions. But strategic thinking, reflecting policymakers' longer-term macroeconomic judgments about how the economy works, is a matter about which heavy disclosure is likely. Policymakers, both in the 1970s and today, want the public to know their thoughts about the causes and costs of inflation, and about the links between economic management and economic outcomes. ${ }^{11}$

How representative are the statements? There are several reasons for being confident that the material I present gives a representative picture of policymakers' views. First, my procedure of

\footnotetext{
${ }^{11}$ This contention is supported by the contents of material on 1970 s economic policy in the United States that has been declassified since my 2005 article. That article applied to U.S. policy the same methodology that I use in this paper. The 1978 Federal Open Market Committee transcripts, released in 2007, support my characterization of Federal Reserve Chairman G. William Miller's views based on his public statements.
} 
looking at contemporaneous statements by policymakers automatically avoids the risk of relying on ex post rationalizations that might appear in retrospective accounts by former policymakers. The potential unreliability of retrospective accounts is illustrated by the case of Federal Reserve Chairman Arthur Burns in the United States. Romer (2005, 181) judges that Burns's 1979 account of his 197078 period as Chairman contains "a substantial amount of wishful revisionism." In addition, it is not widely known that Burns (1978), often cited as a complete collection of Burns's public statements as Chairman, is actually a very partial collection, omitting some of the most unorthodox remarks about inflation that Burns made over 1970-78 (including an item from 1977, quoted in section 5 below). The problem of revisionism extends, of course, beyond the specific example of Burns. My methodology overcomes this problem by using contemporaneous material instead of long-after-the-fact accounts.

Second, by relying heavily on newspaper reports, I in effect pool multiple sources of information about policymakers' views. Consider the case of Japan. Bank of Japan statements are useful for providing technical details about the thinking behind policy choices; but Bank of Japan publications, besides often not being available in English, may not give adequate coverage of statements by members of Cabinet, who were the most senior policymakers. But newspaper accounts provide coverage of the statements of many policy figures, including both Cabinet members and Bank of Japan officials.

Third, while no account of 1970s developments can hope to provide a completely exhaustive collection of policymaker statements about inflation, the hypothesis that I advance is not one that lends itself to selection bias. The reason is that if, as I argue, German and Japanese policymakers initially subscribed to a cost-push view of inflation, this implies that they could not have been guided by the sorts of views prominent in other explanations for 1970s behavior. Embracing a cost-push view of inflation means that one does not believe in a link between the output gap and inflation. Therefore, if policymakers subscribed to a cost-push view of inflation, the following are ruled out as descriptions of policymaker behavior: that policymakers attempted to exploit an inflation/unemployment trade-off, that the absence of a 
disinflation reflected sacrifice-ratio calculations on the part of policymakers, or that the monetary authorities deliberately permitted inflation by consciously accommodating nonmonetary shocks. ${ }^{12}$ The monetary-policy-neglect hypothesis therefore cannot be lumped in with most other hypotheses as part of a "portmanteau" explanation of $1970 \mathrm{~s}$ policies. If you believe in the monetary-policyneglect hypothesis, you cannot endorse most of the other hypotheses, even as partial explanations. In line with this contention, I show below that policymakers' embrace of cost-push views was frequently accompanied by their rejection of other views of inflation behavior.

Finally, in the material from which I have obtained the quotations used in this paper, there exist many alternative quotations, carrying the same message, which could be substituted for the ones I present. Selection of material for this paper does not in practice mean excluding information that contradicts my hypothesis; on the contrary, space limitations confine me to presenting only a subset of the material that supports my hypothesis.

All in all, there are grounds for considerable confidence that the statements quoted here are representative of official views on inflation during the 1970s and would not be overturned by a more exhaustive presentation of policymaker statements.

\section{Japan}

This section studies Japan's Great Inflation and disinflation in detail. The documentary source used to obtain contemporaneous statements by Japan's policymakers is principally the Tokyo English-language daily newspaper, the Japan Times, which during the 1970s also provided translated excerpts from other Japanese dailies. In addition, I draw on coverage of Japanese economic policy that appeared in the Asia-region newspapers South China Morning Post (Hong Kong) and Straits Times (Singapore), as well as material

\footnotetext{
${ }^{12}$ The implication runs in the reverse direction too. For example, a policymaker who believes that higher inflation is the price that must be paid to buy lower unemployment is in effect subscribing to the belief that inflation is sensitive to the output gap, and so is rejecting the cost-push view of inflation.
} 
in newspapers from the United States, the United Kingdom, and other countries.

\subsection{9-73: Increasing Monetary Policy Neglect}

At the end of the 1960s, Japan remained on a completely fixed exchange rate. What domestic policymakers thought about how to control inflation nevertheless mattered greatly - first, because there was considerable monetary policy autonomy in practice despite the fixed exchange rate; second, because erroneous views about inflation behavior meant that the implications of the fixed-exchange-rate regime for inflation control were misunderstood.

In this light, it is significant that as of late 1969, Japanese policymakers characterized the control of inflation as largely separate from monetary policy. Prime Minister Sato said in the Diet: "The stabilization of consumers' prices is the important task for protecting the national livelihood, and it is here that the Government has devoted its greatest effort. While restraining as far as possible the prices of public utilities, I intend to stabilize the consumers' prices through strong policy drives for further growth in productivity, mobility of the labor force, and liberalization of imports" (JT, December 2, 1969).

While denying that excess demand currently existed, the authorities did acknowledge the prospect of an excess emerging and thereby becoming a source of inflationary pressure. The Bank of Japan's discount rate was raised to 6.25 percent in September 1969, with Finance Minister Fukuda citing "the pace of demand expansion" and the risk of overheating as the reason for the change ( $A U P$, October 7, 1969). While it may seem jarring to see domestic factors alone given as the reason for the interest rate increase, it is true that foreign-exchange controls gave Japan's authorities considerable liberty in manipulating domestic interest rates while maintaining a fixed exchange rate. ${ }^{13}$ Apparently, however, policymakers were satisfied that this single tightening was sufficient; after the 1969 increase, the discount rate was held constant until October 1970, when it was

\footnotetext{
${ }^{13}$ Consistent with this, Rasche $(1990,35)$ observes that there are very large discrepancies in the behavior of short-term market interest rates across the United States and Japan over the quarter-century 1956-80, a period that includes the 1969-80 period studied here.
} 
reduced to 6 percent. The reason for this reduction, it was reported, was that Japan's policymakers believed that monetary restriction had achieved its purpose of slowing down the economy (JT, October $28,1970)$.

The Japan Times editorialized in February 1970 that wage increases in the preceding four years had been "determined by the strong-arm tactics of labor unions.... If this trend continues ... [it] may create a serious 'cost inflation'" (JT, February 1, 1970). The government was likewise disposed to analyzing inflation in terms of unit-cost developments but at this stage was less inclined to appeal to wage push as a source of inflation. Vice Minister Kashiwagi expressed a relaxed view: "I anticipate no difficulty because of this rate of wage increase, for worker productivity will increase [by] up to 15 per cent a year and industry therefore will be able to offset the wage increase" ( $A Z R$, May 13, 1970).

In July 1970 Miyohei Shinohara, an official of the Economic Planning Agency (EPA), called for an incomes policy to cover both wage and nonwage incomes (JT, July 10, 1970), and in December the EPA cited wage push as a source of prospective stagflation in Japan. This was noted as "the first time that the danger of a 'cost-push' inflation has been warned in an official government document" ( $J T$, December 5, 1970). It would be inaccurate, however, to say that cost-push views had not guided official policy by this point; the government's efforts in 1969 to restrict increases in public services' prices were informed by cost-push analysis, and this approach continued in December 1970 with an indefinite freeze on public charges (JT, December 10,1970). The elevation of wage push to the top of the government's list of cost-push factors was confirmed when Prime Minister Sato himself cited wage push. He signaled that a formal incomes policy was an option: "I am afraid the Government might have to adopt an incomes policy under the circumstances.... An incomes policy never has succeeded anywhere in the world, but as prices will not become stabilized as long as large pay raises continue, I would like to work out some countermeasures" (SCMP, December 12, 1970).

From a monetary perspective on inflation, the really urgent countermeasure Japan needed was greater exchange rate flexibility, a precondition for an assured monetary policy tightening within Japan. But Bank of Japan Governor Sasaki denied that revaluation would 
help, claiming that the German experience confirmed this (JT, March 11, 1971). The opposition to revaluation was rendered moot by what in Japan was labeled the "Nixon shock": the measures that included U.S. dollar devaluations in August and December 1971. The Bank of Japan cut interest rates over this period, with the discount rate in early 1972 standing at 4.75 percent, the lowest level since 1948 (JT, May 31, 1972). As well as being aimed at restraining the exchange rate, these cuts had a domestic motivation: the Japan Times noted that the government was attempting "to take up the slack in the private sector of the economy ... [via] a low rate [of] interest policy" (JT, January 4, 1972). The Times claimed that any inflationary impact of such stimulus would be precluded by the "big excess capacity in the economy" (JT, January 14, 1972); indeed, it said that this policy might help inflation by cutting business costs. In late 1972, Governor Sasaki expressed satisfaction that the economy was recovering but not overheating (JT, December 25, 1972), and it was not until February 1973 that a Bank of Japan official said that the output gap was now almost closed (JT, February 8, 1973). ${ }^{14}$

\subsection{3-74: Monetary Tightening}

Two events combined to create the conditions for a significant monetary policy tightening from March 1973: first, the collapse of the remaining Bretton Woods arrangements, and second, the recognition that the economy was overheating. Even according to the nonmonetary view of inflation, a positive output gap produces inflationary pressure and justifies a tightening of aggregate demand. As noted above, under the fixed-exchange-rate regime, Japan's policymakers retained some discretion with respect to domestic interest rates. But over 1971-73 there had been repeated cuts in these rates, so monetary policy had, if anything, reinforced the tendency for the fixed

\footnotetext{
${ }^{14}$ Ueda $(1993,193)$ confirms that the Bank of Japan relied on output-gap measures that underestimated the strength of demand in 1972-73. Since the Bank in early 1973 realized that the gap was closing rapidly, it at least had a more accurate estimate of the output gap than those provided at the time by the Organization for Economic Co-Operation and Development (OECD) (1973, 22), which gave Japan's output gap as -5.9 percent for 1972 on average and as -5.0 percent for the second half of 1972 .
} 
Figure 1. Inflation and the Discount Rate in Japan

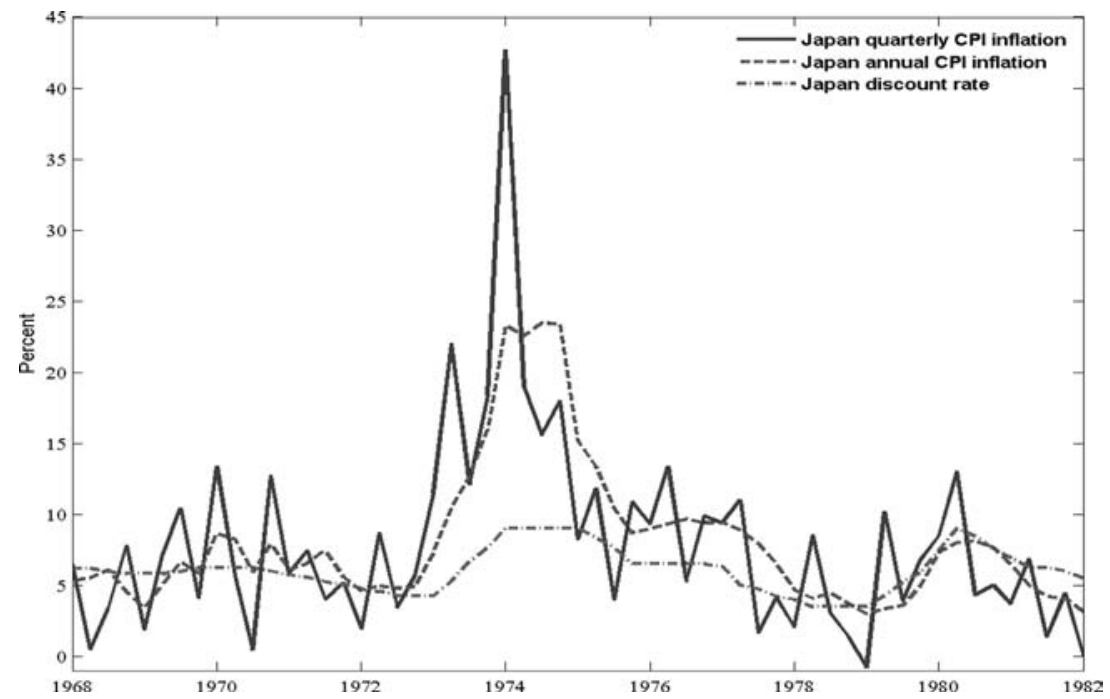

Note: Calculated from Haver-International Financial Statistics data.

exchange rate to generate monetary expansion. This ease now began to be removed. The Bank of Japan's discount rate was increased by 75 basis points in March 1973, and Prime Minister Tanaka approved another increase in May 1973 with the statement that he would "tighten the credit squeeze in order to restrain total demand" (JT, May 26, 1973). As one Japanese news commentary put it: "Now that the prerequisite [of fixed exchange rates] is gone, the central bank focuses its attention on curbing inflation" (NKS, April 11, 1973).

Though a record in nominal terms, the discount rate was well below inflation throughout 1973 and subsequently (see figure 1). But more important was the direction of monetary policy implied by discount-rate choices. Not only did market rates such as the call rate have a considerable spread above the discount rate, but changes in the discount rate seem to have had a more than onefor-one impact on the call rate during the 1973-74 monetary tightening (figure 2). Combined with their impact on other asset prices such as the exchange rate, the 1973 discount rate increases packed 


\section{Figure 2. Short-Term Interest Rate Changes in Japan}

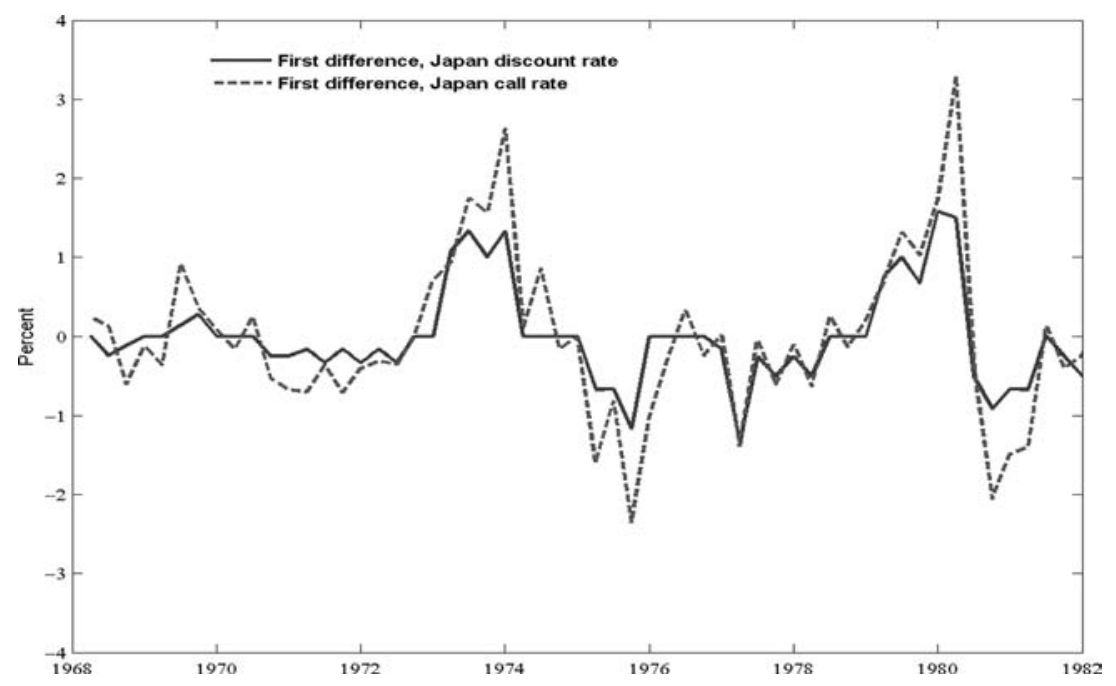

a considerable punch, confirmed also by the sharp slowdown in M2 growth from $1973 .{ }^{15}$

The Japanese government was, however, by no means convinced that eliminating demand pressure was all that was needed to curb inflation, and in April 1973 the government announced several measures inspired by the cost-push view, including increased surveillance of prices of both domestic and imported goods (JT, April 14, 1973). Supporting this eclectic approach, the president of Tokai Bank was reported as favoring "nonmonetary measures in order to curb inflation." Such views, the Japan Times reported, were in line with "the belief held by many economists here that the Japanese economy is faced with "composite inflation" "-i.e., cost-push alongside the excess-demand problem - "which cannot be suppressed by conventional monetary instruments" (JT, May 30, 1973). Monetary tightening was seen as helpful in moving the output

\footnotetext{
${ }^{15}$ The fact that other key yields moved in the same direction as the discount rate over the 1970s, albeit not proportionally, supports the focus on that rate in the discussion here. That is, while many asset prices matter for aggregate demand, their reaction to monetary policy operations is assumed to be approximately collinear with that of the short rate. This approximation is also that taken by West (1993) in studying the post-1973 period.
} 
gap to zero and thereby removing excess demand as a contributor to inflation; but, it was believed, this would still leave inflation in the system that had to be attacked with nonmonetary instruments. Always implicit in this position was the view that negative output gaps did not exert negative pressure on inflation. The Nihon Keizai Shimbun newspaper ${ }^{16}$ endorsed this view, claiming that "it is no longer possible to curb inflation by tight money alone" (NKS, May 30, 1973).

In July 1973, Prime Minister Tanaka said he expected the monetary tightening to bring inflation back under control during OctoberDecember, and if this did not occur, he would consider a wage freeze (JT, July 6, 1973). His overconfident statement reflects lack of appreciation for the length of lags between monetary policy actions and inflation. What is more, he was making a statement that, if proved wrong, would reduce public confidence in monetary tightening as the solution to inflation.

This unwise statement did not, however, lead to a change in monetary policy strategy. When, in November, high inflation was still proceeding, Tanaka judged that demand remained too strong (JT, November 2, 1973). In December 1973, he said categorically, "The present situation does not warrant the adoption of an incomes policy" (JT, December 9, 1973). The government's reaction in December 1973 to continuing inflation and the OPEC oil shock did include some nonmonetary attempts to fight inflation, such as a freeze on rice prices and rail fares ( $J T$, December 22, 1973a). But a prominent role was given to what the government called "utmost efforts ... to curb total demand" ( $J T$, December 22, 1973a), including a 2 percent increase in the discount rate to a record 9 percent (JT, December $22,1973 b)$, implying also a sharp increase in the nominal call-money rate (see figure 2).

\subsection{4-75: On the Brink of a U-turn}

While following restrictive demand policies, the government continued to hold the position that wage push could produce an independent effect on inflation. Prior to the 1974 wage negotiations,

\footnotetext{
${ }^{16}$ According to the New York Times, the Nihon Keizai Shimbun was "Japan's leading economic newspaper" during this period (NYT, June 12, 1974).
} 
Prime Minister Tanaka urged labor to "exercise restraint," stating, "Excessive wage increases ... invite higher prices" (JT, February 22, 1974). The Economist claimed that it was "hard to see where prices will stop" unless an incomes policy was introduced (TE, January $5,1974)$, and when the outcome of the spring wage negotiations was 30 percent nominal-wage growth, an economist at the Japan Development Bank said that Japan was now approaching "fastpaced cost-push inflation" that aggregate-demand measures could not cure (JT, June 21, 1974). Similarly, Finance Minister Ohira said in August 1974 that cost-push pressure, manifested in the "vicious circle of prices and wages," was Japan's main economic problem (JT, August 3, 1974).

In January 1974 Japan's annual CPI inflation passed 20 percent. It stayed above 20 percent throughout the year. In response, costpush views strengthened in policy circles and threatened to produce a major policy change in late 1974. In October 1974, the Cabinet set a goal of limiting inflation to 15 percent, with the Prime Minister's Office seeing restraint on public utility prices as a key weapon $(J T$, October 12, 1974). These had featured in anti-inflation packages in previous years; their continued use did not in themselves augur a major policy change. But Prime Minister Tanaka also indicated he would not rule out introducing wage controls, and he was quoted as wishing "to sever the vicious cycle of prices and wages, and promote harmony between the wage problem and the whole national economy" (SCMP, October 8, 1974). More promisingly, these official pronouncements were not at the expense of continuing monetary restriction; rather, as the Japan Times put it, there remained "a fairly solid and welcome consensus among Government leaders that the restrictive demand management policy should be continued for the supreme objective of slowing inflation" (JT, October 23, 1974). Later in October, however, the Bank of Japan's governor said, "We have reached a point where money can't be tightened any further" (JT, October 29, 1974), and in December Deputy Prime Minister Fukuda said that Japan's inflation was now "cost-push" (JT, December 19, 1974).

The decline in inflation in 1975 (see figure 1) was sufficiently dramatic to hold off a shift to a nonmonetary strategy against inflation, and official statements during 1975 took a more orthodox tone. In particular, demand restriction was reaffirmed as effective against 
inflation, and a negative output gap was seen as removing inflationary pressure. Deputy Prime Minister Fukuda said that while production was stagnant, "the problems of prices and wages are still a matter of great concern and, therefore, the demand-curbing policy should be continued" (JT, January 18, 1975). Similarly, Prime Minister Miki said that while "there is no denying the fact that business is becoming increasingly stagnant," continuing inflation meant "it is not feasible to lift the current restrictive measures on total demand" ( $J T$, January 25,1975$)$. While the discount rate had not been raised during the very large increase in inflation in 1974, neither was it reduced during the first quarter of 1975, by which time statistics were indicating that the economy had contracted during 1974 and that annual inflation was falling rapidly. The fall in inflation was generally recognized as a reaction to the demand restraint: e.g., a correspondent for Singapore's Straits Times observed, "Japan's determined anti-inflation campaign is beginning to slow the rise in prices.... [T] he inflation rate ... seems to be coming down because of the recession" ( $S T R$, January 29, 1975). This was a breakthrough because the recession was widely seen, including in official estimates ${ }^{17}$ as having turned the output gap sharply negative - a "deep slump" in the New York Times' estimation (NYT, June 12, 1974). Therefore, to attribute the inflation decline to weak aggregate demand was to reject the cost-push position that negative gaps do not pull down inflation.

\subsection{5-79: Entrenching the Monetary Control of Inflation}

The first change to Japan's discount rate since 1973, a 0.5 percent cut to 8.5 percent, was made in April 1975. Bank of Japan Governor Morinaga announced the cut with the following caveat: "The discount rate cut does not mean a drastic policy shift; only the signal has changed, from red to reddish yellow" (NKS, April 16, 1975). This was a modest cut compared with that being urged by the Prime Minister's Price Stabilization Council, which had advocated a 150-basis-point reduction and had argued that such a move would be anti-inflationary by cutting business costs (JT, April 21, 1975). The

\footnotetext{
${ }^{17}$ One such official estimate was in an Economic Planning Agency report released in August 1975 (STR, August 19, 1975).
} 
maintenance of monetary restraint reflected the fact that cost-push views like this were continuing to lose influence. But interest-costpush views did creep into Deputy Prime Minister Fukuda's analysis when he justified an additional 50-basis-point cut in June 1975 as one that would stimulate the economy and reduce pressure on prices (JT, June 9, 1975).

The predominant trend continued to be in the direction of further endorsement of the monetary view of inflation. The president of the Bank of Tokyo said in May 1975 that the "policy of restraining aggregate demand, especially on the monetary front, that had been pursued since the beginning of 1973, has resulted in a pronounced slowing of price advances this year" (JT, May 31, 1975). The government white paper on the economy attributed 1973-74's inflation largely to excessive demand and said that inflation had been reduced at the cost of recession (JT, August 9, 1975; JT, August 14, 1975). Further evidence of the impact of the monetary restriction came in late November, when it was revealed that nationwide annual CPI inflation had fallen below 10 percent in October, the first single-digit outcome since early 1973 (JT, November 29, 1975).

By March 1976, it was clear that the government had achieved its goal of bringing down inflation to single digits for the 1975-76 fiscal year (JT, March 29, 1976), and its aim for 1976-77 was to bring inflation down further to a maximum of 8.6 percent (JT, January 29,1977$)$. From a monetary perspective on inflation, a decline of this magnitude was close to being locked in by the prior period of monetary restraint and subsequent permanent reduction in money growth. From a cost-push perspective, there was no such guarantee, and the Japan Times, taking this approach, was pessimistic: "Cost-push inflationary pressures remain strong... There is indeed a possibility that we might see the inflation rate soar to a doubledigit level again" (JT, November 15, 1976). Inflation for the fiscal year ending in March 1977 ultimately came in at 9.4 percent $(J T$, April 29, 1977), an interruption of the decline since 1974. The government set a target of 7 percent for fiscal year 1977-78 (JT, April $28,1977)$. The overshoot of the 1976-77 target proved to be an aberration, out of line with the monetary restraint observed since 1973; it was compensated for by the rapid decline in inflation in 1978. In July 1978, the Japan Times observed, "Perhaps the most striking development on Japan's domestic economic scene today is regained 
price stability" (JT, July 26, 1978), with CPI inflation around 4 percent, well below the 7 percent maximum target. Nevertheless, the article acknowledging this achievement attributed it to the recent yen appreciation rather than the turnaround since 1973 in monetary policy.

All these developments were against the background of the major post-1973 productivity slowdown. Much commentary in Japan in 1973-74 accurately saw the economy as undergoing a permanent shift in its trend growth rate. For example, the Japan Times editorialized at the end of 1973 that it was "broadly discerned that the country must save energy consumption and settle for a much lower rate of growth in the future" (JT, December 30, 1973), while Finance Minister Fukuda said in May 1974 that in coming years Japan would seek a growth rate "acceptable by international standards" and could not return to the 15 percent growth rates experienced in the past (JT, May 10, 1974). So estimates of the output gap in the years following 1973 were not on the grossly erroneous scale that would have resulted from assuming no change in the trend of potential output in years after $1973,{ }^{18}$ but the magnitude of Japan's slowdown did mean substantial output-gap errors. An OECD report released in mid-1977 gave Japan's output gap as about -13.5 percent as of the end of 1976 (McCracken et al. 1977, 84). This was likely more pessimistic than the Japanese government's estimates of the output gap, for the OECD, unlike the government, did not acknowledge any quarter of positive output gaps in Japan since 1970, not even in $1973 .{ }^{19}$ Within Japan, the Japan Times in late 1977 said there was a "huge surplus of productive capacity" of "well over 10 trillion yen" (JT, September 8, 1977) - i.e., an output gap of at least -6 percent. The government itself set a real-GDP-growth target of 7 percent for 1978-79 (JT, January 22, 1978) and, in pursuit of

\footnotetext{
${ }^{18}$ Thus official estimates were not as severely in error as those later given by Brown and Darby $(1985,71-75)$, who estimated potential output by fitting a loglinear trend to Japan's real GDP over 1952-79. Because it was heavily affected by the pre-1974 trend, Brown and Darby's procedure resulted in a negative and continuously worsening output-gap series for Japan over 1976-79, with the 1979 output gap more negative than -12 percent. In contrast to this series, estimates of the output gap used by Japanese authorities in the late 1970s did record that the output gap was becoming less negative over 1978-79.

${ }^{19}$ See Laidler $(1978,1043)$.
} 
this, the discount rate continued to be cut, to 3.5 percent in early 1978, with implied bank lending rates of about 5.9 percent ( $J T$, March 16, 1978; JT, June 23, 1978). In October 1978 the administrative councilor of the Economic Planning Agency gave Japan's output gap as -11 percent as of the previous March (JT, October 6, 1978).

Despite this perceived large gap, the authorities in April 1979 increased the discount rate for the first time since 1973. Analyzing this increase, the Japan Times said that "the Bank of Japan let it be known on Monday that it is determined to fight a resurgence of inflation" ( $J T$, April 18, 1979), with the authorities in particular wishing to avoid excessive money growth of the kind observed in 1972-73, and to forestall a continuation of rising wholesale price inflation. Discussing the increase in wholesale inflation, an official government bulletin cited rising oil and commodity prices but also acknowledged that "improvements in the supply and demand situation" - that is, a diminishing output gap - were a contributing factor (JT, June 26, 1979). This contrasts with the authorities' position in 1972, when they did not regard a narrowing of the gap as a signal for tightening. The change in the gap was now given weight in policy decisions - thus embedding into monetary policy a "speed-limit" dimension, in the terminology of Walsh $(2003) .{ }^{20}$

In late 1978, the approach of basing policy decisions on variables other than the estimated output-gap level was consolidated when the Bank of Japan announced forecasts for M2 growth (see, e.g., Hamada 1985). These were not formally labeled targets, but Bank of Japan Governor Morinaga said, "I'll carry out monetary policy while closely watching the movement of money supply" ( $N Y T$, December 28, 1978). Thus, even before the series of discount-rate increases began in 1979, Morinaga had signaled that high money growth would lead the authorities to raise interest rates.

Not only were the authorities tightening ahead of much of the actual increase in CPI inflation, but they were still ahead of much opinion on the role of monetary policy in fighting inflation. A May 1979 commentary in the Kyodo News Service on the Bank of Japan's

\footnotetext{
${ }^{20}$ See section 4.5 below for further discussion.
} 
discount-rate increase was entitled "Credit Policy Unlikely to Affect Inflation." It said that strengthening demand had "not as yet been much of a factor" in wholesale price increases and downplayed the contribution monetary policy could make if CPI inflation did worsen: "[R]eliance must be put on other policy measures. Fiscal policy will have to be tightened.... More vigorous action must be taken to strengthen the yen's exchange rate and bring down the cost of imports. Imports, especially of manufactured goods, must be increased.... The means to check inflation are readily available" (KYO, May 23, 1979).

Further discount-rate increases took place over 1979-80, with a 100-basis-point increase in February 1980 justified by Bank of Japan Governor Mayekawa as an inflation-containing action in the face of a tightening of the demand-supply position (JT, February 19, 1980). In contrast to the tentative support for incomes policies voiced by policymakers during 1970 and 1974, a Bank of Japan official observed the following in 1980: "No incomes policy could conceivably be effective.... [O]rthodox policies ... are valid enough to check home-made inflation." 21

\subsection{Lessons from Japan's Experience}

Several lessons emerge from Japan's Great Inflation and disinflation. First, while Milton Friedman's (1990, 107) observation that "no control of individual prices nor of individual wages" occurred during the 1973-74 monetary tightening is an overstatement-Japan's officials did impose limits on price increases on specific goods - the controls applied to a small portion of the price index, and inflationary pressure suppressed by the controls could easily be transferred to other prices. Therefore, Japan's disinflation cannot plausibly be attributed to incomes policy.

Second, Japan, like other countries, had a period during which policymakers were inclined to adopt general wage and price controls because they believed inflation had become cost-push in character. But in Japan's case the strongest doubts came just before a drastic decline in inflation in 1974-75, and this decline, coming in the wake

\footnotetext{
${ }^{21}$ Suzuki (1981, 412).
} 
of severe monetary restraint, served as a powerful rebuttal of the view that inflation was insensitive to negative output gaps.

Third, the recognition by Japan's policymakers of an excessdemand problem in 1973 was superior to that of outside agencies such as the OECD (1973). This may have reflected greater weight given to money (M2) growth, which had risen about 8 points over 1970-73, as an indicator of pressure on aggregate demand.

Fourth, the post-1973 slowdown meant that Japanese policymakers' output-gap estimates were probably substantially biased in the later 1970s; nevertheless, disinflation proceeded over these years. Again, the emphasis on money growth may have helped in reducing the weight given to gap estimates. But Japan's officials also indicated that they tightened monetary policy in response to positive output-gap growth. This "speed-limit" policy reaction could be rationalized by a variety of theories. The most traditional, but least consistent with modern inflation analysis, is that the growth rate of the gap appears directly in the Phillips curve. More consistent with a New Keynesian analysis is the view that output-gap changes suggest revisions to the expected path of the output-gap level, and so a revised inflation forecast. Responding to them is in effect a backdoor way of responding to the correctly measured (expected path of the) level of the output gap. Regardless of the specific rationale, emphasis on output-gap growth insulates monetary policy decisions from output-gap mismeasurement, since errors in level estimates tend to be persistent and largely cancel from the growth rate, as discussed in Giannoni (2002), Orphanides (2003), and Orphanides and Williams (2006).

In the present instance, there was a specific type of output-gap error that policymakers' response to growth rates protected against: the actual late-1970s output gap in Japan was closed well before real-time estimates of the gap stopped being negative. Percentage changes in variables have turning points that precede those of their corresponding levels, ${ }^{22}$ so a policy tightening in response to an estimated positive output-gap growth rate proved, ex post, to be a tightening in response to an actual positive output-gap level.

\footnotetext{
${ }^{22}$ See, e.g., Culbertson (1960) for a vintage discussion.
} 


\section{Germany}

This section covers the inflation-disinflation experience in Germany over 1969-80. I draw on coverage of, and commentary on, monetary policy and inflation in the German press; similar discussions of Germany in several other countries' newspapers; and Bundesbank reports, speeches, and testimony.

\subsection{9-71: Orthodox Response to Inflationary Pressure}

Germany was more integrated than Japan into the international financial system over the Bretton Woods period, and so its policymakers' scope to vary the official discount rate for reasons other than the exchange rate parity was more limited than their counterparts' in Japan. Beginning in the late 1960s, however, the authorities began taking steps to shield Germany from U.S. monetary expansion. These measures included temporary exchange rate floats in late 1969 and May-December 1971, and an intensification of foreignexchange controls in mid-1972, discussed below.

The limited monetary policy independence bought by these measures led to a series of monetary tightenings, including an increase in the discount rate from 6 percent to 7.5 percent during March 1970. Economic overheating and inflationary pressure were cited as reasons for the tightening, with the Bundesbank's vice president, Otmar Emminger, observing, "If there is no improvement in wage and price developments, we'll naturally be forced to go on making monetary policy very restrictive" (DS, July 20, 1970, a.t.). By the time this statement was published, however, the constraints imposed by the exchange rate policy had been made plain by the Bundesbank's removal of some of its March tightening, with the discount rate cut from 7.5 percent to 7 percent in July (WSJ, July 16, 1970). With its room to move on interest rates limited, the Bundesbank attempted to rely on reserve-requirement increases in April and June 1970 (JT, June 20, 1970), measures unlikely to affect aggregate demand when not accompanied by interest rate increases.

A speech by the Finance Minister, Karl Schiller, in September 1970 clearly recognized the absence of a long-run inflation/unemployment trade-off: "Inflation is like a drug. For a short time it makes our society feel 'high'.... Then it becomes apparent 
that the 'trip' has not solved any problems, and even created new ones." Schiller was, however, eclectic in his picture of the solution to inflation, describing incomes policy, monetary policy and fiscal policy as "complementary sets of policy instruments" (AUP, September $24,1970)$.

\subsection{1-72: The Monetary-Policy-Neglect Period}

It was from early 1971 until mid-1972, in the wake of double-digit annual nominal-wage growth in 1970-71 and the apparent elimination of excess demand, that cost-push views reached their high-water mark in German debate. As early as January 1971, an authoritative statement making heavy concessions to the cost-push view appeared in the form of an address by Bundesbank President Karl Klasen. In line with cost-push views, Klasen endorsed the position that present wage-growth rates were "not justified by economic conditions," excess demand having passed. Klasen saw the German government's "Concerted Action" program - a consultation process among labor, firm, financial, and government leaders - as a potentially valuable anti-inflation instrument. Nevertheless, Klasen demonstrated that thinking in Germany at this point was more orthodox than elsewhere. In contrast to Federal Reserve Chairman Arthur Burns's position at the time, Klasen deplored compulsory price controls as part of the solution; moreover, he rejected the view that monetary policy actions had become ineffective, and indeed indicated that the Bundesbank's recent decision not to cut the discount rate reflected a wish "to prevent continuing price rises" (AUP, February 2, 1971).

In the same spirit, continuing inflation (at about 4.5 percent per annum) and the danger that monetary easing could help transfer wage pressure into price inflation were cited by the Bundesbank when it again held the discount rate constant in March (IP, March 18, 1971). This position received support from a front-page editorial entitled "Cost Inflation" in the Frankfurter Allgemeine Zeitung. Proclaiming that it was "unambiguous how strongly the wage spiral has contributed to the decline in the value of money," the newspaper rejected the view of "some critics ... that the Bundesbank's measures are not effective" and supported monetary restraint as a response to wage push (FAZ, March 18, 1971, a.t.). 
This position was in harmony with the monetary view of inflation, which states that monetary policy can block current wage developments from spilling over into expectations of future price inflation.

But it was over precisely this period, early 1971, that a shift took place in official opinion away from orthodox views on inflation behavior. The motivation for this shift was the change in the aggregate-demand picture. Estimates by the OECD constructed in early 1973 (OECD 1973, 29-32) suggested that Germany's output gap peaked at +1.3 percent in the first half of 1970 , averaged +1.0 percent in the first half of 1971 , and turned to -1.5 percent in the second half of 1971 . These were not based on German government sources, but the January 1971 statement by Bundesbank President Klasen mentioned above indicates that German policymakers thought the gap was 0 by 1971:Q1. Therefore, like the OECD, German policymakers thought that excess demand had peaked in 1970, but unlike the OECD, they believed it had dissipated by early 1971.

With inflation rising during 1970 and 1971, policymakers and opinion leaders were susceptible to explanations for inflation that attributed it to nonmonetary factors - instead of (correctly) viewing the inflation as the result of the pre-1970 monetary ease working its way through the system. As we have seen, by early 1971 Klasen was already attributing substantial wage inflation to cost-push forces. Therefore, the longer price inflation proceeded at high rates after 1970, the more likely it was to be attributed solely to factors other than excess demand. Sure enough, Jürgen Husmann, the deputy economics director of the German Employers' Federation, said in March 1971, "[T] he recent price increases are not demand-induced. They arise from increases in wage costs" (DT, April 1, 1971). The Financial Times had already been quick off the mark, stating in January 1971 that "the easing of demand pressure has had no effect on the inflationary wages-prices spiral.... German inflation is now of the cost-push rather than the demand-pull variety, and consequently more difficult to control" (FT, January 1, 1971).

Assessments like this prevailed in policy circles too, with Finance Minister Schiller in September 1971 describing "cost pressures" as a separate cause of inflation distinct from excess demand (AUP, October 5, 1971). Indeed, shortly after the May 1971 exchange rate 


\section{Figure 3. CPI Inflation in the Federal Republic of Germany (FRG)}

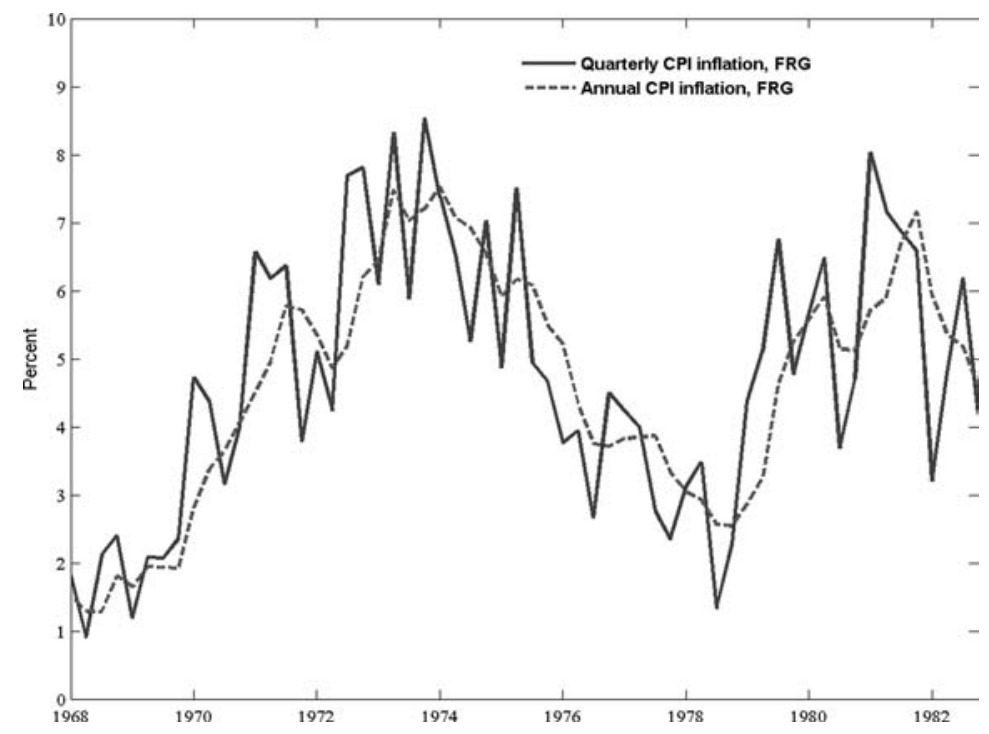

float, Schiller saw the economy as having featured the removal of overemployment, and he believed "a new chapter" had begun, with incomes policy (the Concerted Action) playing a large role in controlling inflation (DW, June 23,1971 , a.t.).

This "new chapter" indeed featured distinct policies from 1970, including looser monetary policy. The dissipation of monetary restraint was evident in a 2-percentage-point decrease in the discount rate over calendar-year 1971; this occurred despite annual CPI inflation rising about 2 points during the year (see figure 3 ). The interest rate cuts continued over the May-December 1971 interval, which the Bundesbank considered a floating-mark period $(B B A R$, April 1972, 18), so it is difficult to argue that these cuts reflected policymakers balancing inflation control against exchange rate stability. Rather, the belief that inflation could be solved by incomes policy implied that monetary policy was free to stimulate the seemingly weak economy. Overambitious goals for incomes policy had been made public in January 1971 by Bundesbank President Klasen, who had voiced the opinion that Concerted Action offered the prospect of moving from a situation where "[union] members judge the success 
of the trade union leadership on the success of the wage struggle" to "a higher level" where "the performance should be judged on trade unions' part in the general economic report of the Federal Government" ( $D W$, January 23, 1971, a.t.).

Finance Minister Schiller resigned in mid-1972 in protest against new policy decisions, including the adoption of exchange controls (Fels 1977, 613). Since Schiller was arguing for a freer financial system, it would be tempting to conclude that his defeat was a further setback for orthodox macroeconomic policies. That would not, however, be an altogether appropriate conclusion, since Schiller's departure increased the Bundesbank's ability to carry out monetary tightening. Schiller favored a fixed exchange rate with minimal exchange rate controls; but if monetary restraint was to commence under fixed rates, Germany needed foreign-exchange controls. With these controls imposed, the German authorities were indeed able to raise interest rates in late 1972 . From a monetary-control perspective, the reimposition of exchange controls was desirable. The policy package involving foreign-exchange controls was thus the lesser of two evils, even though less appropriate than the alternative, notyet-on-the-table option of a permanent float, monetary restraint, and no exchange controls.

Schiller's departure was also beneficial in promoting a shift away from incomes policy as an anti-inflation weapon. In August 1972, shortly after assuming office as Finance Minister, Helmut Schmidt was asked to comment on the United States' wage and price controls. His response was to cast doubt on their value: "I think a short-term success of the U.S. experiment is quite possible. But in the long run controls create serious distortions of market forces. You've got to grasp how wedded we are to the concept of free markets and free competition as a foundation of a productive economy. We consider the basically free play of prices on the market and the absolute independence of employer and employee in wage negotiations as vital to this process. I don't really think much of trying to interfere in this autonomous play of forces with such things as wage and price controls" ( $N W$, August 21, 1972). Schmidt's views stand in contrast to the enthusiastic, even utopian, prior statements by Schiller and Klasen to the effect that incomes policy opened up a new chapter in which unions' objective functions were transformed. 
The late-1972 interest rate increases were preemptive in the sense that they amounted to tightening while the output gap was still believed to be negative - the Bundesbank's report on 1972 gave it as -1.5 percent on average $(B B A R$, April 1973, 11). The 1972 tightening was in response to rapid money growth and to the signal this gave of prospective overheating in 1973. Thus monetary policy in 1972 focused on monetary aggregates but did so with a preemptive outlook regarding aggregate-demand developments. There is therefore considerable continuity from late-1972 policy to the late-1974 policymaking described by Bernanke et al. (1999, 47), which they cite as notable for preemption (though a preemptive easing, as opposed to the preemptive tightening of 1972).

\subsection{3-75: New Regime}

The transfer of inflation control to monetary policy, already underpinning the 1972 discount-rate increases, was boosted further in early 1973 , notably in a call by the federal government, documented by von Hagen (1999a, 683), for monetary policy to carry out disinflation. While von Hagen emphasizes that this preference for monetary policy reflected the executive branch's reluctance to tighten fiscal policy, for the present discussion, two other very important aspects of the government's call are crucial and put it in a more favorable light. First, it was an affirmation at a high policymaking level that restricting aggregate demand was essential for reducing inflation. This contrasts with, e.g., the United Kingdom and Ireland at the time, with their governments' belief that monetary stimulus actually reduced inflationary pressure. Second, a disinflationary monetary policy was acknowledged as compatible with lack of fiscal consolidation. This contrasts with the position of Arthur Burns in the United States that fiscal deficits automatically pushed up money growth and/or inflation.

During the second quarter of 1973, the Bundesbank raised the discount rate in two steps to 7 percent. At a press conference following the first of these increases, Bundesbank President Klasen affirmed that the increase was designed to fight inflation. He did, however, indicate he might support a wage-price freeze if inflation deteriorated, adding that "we must use all other available measures" before contemplating that step (JT, May 5, 1973). 
A firmer rejection of controls as a solution to Germany's inflation took place the following week, when the Brandt government announced its own anti-inflationary measures, concentrating on fiscal restriction and excluding wage and price controls (SCMP, May 11, 1973). ${ }^{23}$ Commenting on the measures, the "father" of Germany's postwar currency, Ludwig Erhard, applauded the government's rejection of wage-price controls, adding, "I think perhaps we now should have another currency reform in miniature" (JT, June 22, 1973).

In fact, as he spoke, Germany was undergoing a "currency reform in miniature" - in the form of the regime of a floating exchange rate and inflation-oriented monetary policy, started in 1973. Germany's regime change is frequently dated to the announcement of monetary targets in December 1974, a dating also implicit in the estimation of reaction functions on samples beginning in 1975 at the earliest. ${ }^{24}$ But money growth had been cited as a consideration when the Bundesbank began tightening in October 1972 (JT, October 8, 1972). By October 1973, Helmut Schlesinger, a Bundesbank director, was describing March 1973 as the date when "[m]onetary policy ... moved back into the center of anti-cyclical policy" (FT, October 8, 1973). And, indeed, the Bundesbank in 1975 described its 1974 strategy as "to continue the fight begun in 1973 " (BBAR, April 1975, 14), and though monetary targeting was not introduced until the end of 1974, a Bundesbank official testified in 1980 that the Bundesbank "for internal purposes had already established a target for its own orientation for the year 1974" (Dudler 1980, 299).

\footnotetext{
${ }^{23}$ Chancellor Brandt reaffirmed the rejection of controls in a television interview in February 1974: "Such steps have not proved to be effective. In our neighboring countries, such steps did not bring about any better results" (quoted in JT, February 3, 1974).

${ }^{24}$ See, e.g., Bernanke and Mihov (1997). As discussed below, Bernanke et al. (1999, 43-47) do offer official statements that they suggest are evidence of the influence of monetarism on German policy thinking in the period predating official monetary targeting. But the examples they cite, as well as the quotation offered by von Hagen (1999a, 690), are not in fact unambiguous evidence on this point. They could imply that monetary restraint is merely necessary for (or "compatible with," to use the words that von Hagen quotes) inflation control, whereas monetarism treats monetary restraint as necessary and sufficient for inflation control. The material I present is, by contrast, more clear-cut in showing that key Bundesbank personnel embraced the monetary view of inflation.
} 
Therefore, the regime in force from December 1974 was a formalization of that prevailing throughout 1974, itself in turn a continuation of the regime begun in March 1973. Indeed, most of the "heavy lifting" carried out during the regime - substantial interest rate increases - had been done by the time monetary targeting was formally introduced, with the discount rate being cut from October 1974, annual CPI inflation having peaked (at 7.5 percent) in 1974:Q1.

What were the doctrinal changes underlying the regime change? The price-stability task of monetary policy was already enshrined in the Deutsche Bundesbank Act of $1957 .{ }^{25}$ But to regard price stability as the primary task of monetary policy is only part of the way to a modern view of inflation control. What is also needed is recognition that nonmonetary instruments such as incomes policy are redundant and ineffective as means of fighting inflation. Here, changes in personnel at the top of the federal government were an important element, with Finance Minister (from May 1974, Chancellor) Schmidt more inclined than his predecessor to focus on monetary policy and to downplay incomes policy. ${ }^{26}$

As far as the Bundesbank is concerned, however, there is evidence that President Klasen, while supportive of tightening money in 1973, did not undergo a profound change in his views relative to 1971. At that time, he had subscribed to a mixed cost-push/monetary view of inflation, with his behavior from mid-1971 suggesting a move to a harder-line cost-push view, giving up on the idea that monetary actions could rein in wage inflation; further, as noted above, in mid-1973 he had withdrawn his 1971 opposition to compulsory wage and price controls (though the government did not adopt them after all). The monetary policy tightening in 1972-73 was compatible with this position, as it was a reaction to a prospective positive output gap and did not in itself signify a denial of the importance of cost-push factors. Even in June 1974 President Klasen described the monetary tightening as amounting to "[w]hat could be done by monetary means" against inflation, with low inflation also requiring improved attitudes about sharing the economic "cake" $(A B$,

\footnotetext{
${ }^{25}$ See, e.g., Deutsche Bundesbank (1980, 291).

${ }^{26}$ The Bundesbank's Otmar Emminger subsequently noted that Schmidt's arrival heralded a "shake-up ... [of] great significance" (Emminger 1977, 34).
} 
June 27, 1974). Klasen's nonconversion to the monetary view of inflation was also reflected in the Bundesbank's most authoritative statements, such as the 1972 Annual Report, which stated the following on its opening page: "Monetary policy alone cannot avert the danger of inflationary expectations gaining strength" (BBAR, April $1973,1) \cdot{ }^{27}$

A sharper change in attitude to inflation control occurred among other directors of the Bundesbank. Chief Economist Helmut Schlesinger was much more influenced by monetarism, citing "theoretical arguments and empirical findings produced largely in the U.S." Schlesinger noted that a monetary approach to inflation control was "nothing new from the German point of view" (FT, October 8, 1973), but the new research on the subject helped convince Schlesinger that German policymakers had been wrong to look to devices other than monetary policy for inflation control.

Bundesbank Vice President Emminger, like Schlesinger, took a stronger view than President Klasen on the contribution that monetary policy could make. Emminger affirmed that the Bundesbank could deliver price stability, and he spoke out against critics. "For example," he observed in November 1973, "people say: 'Antiinflation policy, well and good; but in the cost of living there's a large proportion of administered prices which are insulated from market laws and thus from the overall instruments of fiscal and monetary policy.' According to this argument, no matter how hard we try, we can never get below a given bedrock inflation rate determined

\footnotetext{
${ }^{27}$ This quotation puts in perspective the statement in the same report that a "persistent and accelerating decline in the value of money is impossible without a corresponding [monetary] expansion ... [and] the monetary sphere in its own right not infrequently promotes the inflation of prices and wages" (BBAR, April 1973, 24). Bernanke et al. $(1999,50)$ interpret this quotation as implying that "monetarism was having a significant impact on policymaking inside the Bundesbank." This conclusion is accurate - see the October 1973 quote from Helmut Schlesinger given here-but does not follow from the quotation, which is a weaker statement than what is implied by a monetary view of inflation. To say that "accelerating" inflation requires monetary accommodation, and that monetary expansion "not infrequently" promotes inflation, could simply be acknowledging that monetary expansion can create excessive demand and compound cost-push inflation. Unlike later statements by the Bundesbank, quoted below, this statement does not reject the possibility that cost-push forces can be a source of maintained inflation, nor does it acknowledge that monetary restraint is a sufficient condition for price stability.
} 
by the administered prices, let us say 5\%." Emminger rejected this "defeatism about the value of monetary policy." The proportion of prices and wages that responded to market forces was large, and he noted that even administered prices ultimately responded to market forces (AUP, November 9, 1973, a.t.).

It is therefore appropriate to conclude that the monetary regime that began in 1973 was influenced by the monetary view of inflation, but President Klasen underwent a less significant change in opinion than his subordinates. To emphasize, this did not amount to a difference among policymakers on the costs of inflation; Emminger and Schlesinger shared the goal of price stability with Klasen. Rather, it amounted to a different perception of what had created price stability before 1970 and what had changed since 1970. Klasen was more concerned with reinforcing specific institutional arrangements that had existed before 1970 such as Concerted Action, believing the need for incomes policy to have become more important in the 1970s. Emminger and Schlesinger had far less attachment to the pre1970 institutional arrangements, be they Concerted Action or fixed exchange rates. Their reasoning was that these features would not secure the truly important element that had been lost since 1970namely, monetary stability. They saw no merit in fixed exchange rates per se, notwithstanding fixed rates being a feature of the earlier price-stability period; monetary stability could be delivered by domestic monetary restraint combined with floating exchange rates, and fixed rates could be an impediment to restoration of monetary stability. Klasen thought monetary restraint was one condition for price stability; Schlesinger and Emminger thought it was a necessary and sufficient condition. ${ }^{28}$

In 1973, however, with unanimity that excess demand was the immediate problem, doctrinal disagreements were less likely to manifest themselves as policy disagreements. This unanimity, and the

\footnotetext{
${ }^{28}$ This conjecture about Emminger's and Schlesinger's 1973 positions is compatible with their later reputation as dissenters in post-1974 Bundesbank deliberations, as indicated by von Hagen's (1999a, 690) discussion of the Bundesbank General Council's minutes. Indirect support for associating Klasen with the nonmonetary approach to inflation is also provided by the fact that neither von Hagen's (1999a) nor Bernanke et al.'s (1999) account of Bundesbank monetary targeting mentions Klasen, despite monetary targeting being inaugurated during his presidency.
} 
solidarity between the government and the Bundesbank on the 1973 policy change, proved important, as the new course was criticized by many leading financial commentators. Jürgen Ponto, president of Dresdner Bank (the Federal Republic's second-largest commercial bank), said in November 1973, "The doubts whether a lasting stabilization of cost and prices can be achieved by holding fast to the current restrictive credit and fiscal policy course are being only reinforced." Ponto claimed that interest rate increases were having a cost-push effect "rather than the desired anti-inflationary effect" (JC, November 5, 1973). The Economist, too, was extraordinarily critical. In June 1973 it asserted: "Chances for an early dip in costpush inflation therefore look slim.... [T]ight money ... will merely turn boomflation into stagflation" ( $T E$, June 9, 1973). In November it editorialized that "the right economic recipe is re-expansion and an incomes policy" and judged that the government's rejection of controls and its embrace of demand restraint "could hardly be a worse policy for Germany at this time" (TE, November 10, 1973).

\subsection{5-80: Consolidating the New Regime}

In the second half of the 1970s, the regime change was consolidated by data outcomes - low inflation - and personnel changes - notably the accession (in 1977) of Otmar Emminger to the Bundesbank presidency. An interview Emminger gave in early 1975, while still Bundesbank vice president, was notable for his emphasis on aggregate demand control. He stressed that Germany had gotten "inflation under control ... [by] apply[ing] the classical medicine of restrictive fiscal and monetary policy." Asked if Germany's monetary policy solution could be applied to the United Kingdom, Emminger expressed the reservation that "[w] hen you already have very high and firmly established inflationary expectations, it is difficult to break them with restrictive fiscal and monetary policy alone" ( $T G$, March 5, 1975). This phrasing of the issue was probably a diplomatic way of avoiding direct criticism of UK policymakers; Emminger was being interviewed by a British newspaper. It is uncontroversial, according to the monetary view of inflation, that monetary policy might not reduce inflationary expectations at the same speed that 
it removes inflationary pressure. ${ }^{29}$ This does not prevent monetary policy from reducing inflation, but it increases the short-term output costs of a disinflation. Incomes policy is sometimes invoked as helpful in these circumstances, by providing a direct link between nominal contract arrangements and the government's disinflation program. The problem with using this as a defense of incomes policies pursued by countries like the United Kingdom in the 1970s is that incomes policy was seen in those countries as an anti-inflation policy in itself, a view Emminger rejected: "it is nearly impossible to break established inflation by relying on incomes policy alone" ( $T G$, March 5 , 1975).

Later in 1975, Emminger was more outspoken about nonmonetary approaches to inflation control. Emminger referred to the "baffling complexities" of incomes policies, and went on as follows: "[W]hatever the initial causes of a particular price inflation-they may be entirely exogenous like bad harvests, the oil price increase, etc. - in the longer run price inflation can continue only if it is accommodated by permissive monetary policies. Inflation is a monetary phenomenon. Thus the responsibility of the central banker is always involved" (AUP, December 19, 1975).

Similarly, in 1977 the Bundesbank's Helmut Schlesinger said, "In the medium run, general price increases cannot occur without excessive expansion of the money stock" (AUP, October 11, 1977). This firmness contrasts with positions of other countries' policymakers at the time, not only elsewhere in Europe but also in the United States. Federal Reserve Chairman Arthur Burns, in one notable statement, said he was confident that monetary policy could prevent inflation only "if private enterprise doesn't go wild and if Congress stops legislating inflation" 30 - so that in contrast to the Bundesbank orthodoxy, monetary restraint in Burns's view was merely one of many conditions for inflation control.

\footnotetext{
${ }^{29}$ That monetary policy can ultimately-whatever short-run inertia exists in inflationary expectations - pin down those expectations fully by keeping the expected output-gap path at zero, distinguishes the monetary view of inflation.

${ }^{30}$ Arthur Burns, November 9, 1977 testimony, in Committee on Banking, Housing, and Urban Affairs $(1977,26)$.
} 
Several practical features of the new monetary regime emerged. ${ }^{31}$ First, the Bundesbank did not accommodate the 1973-74 oil shock. President Klasen said in 1974 that it "would be wrong to inhibit indispensable adjustment processes by artificially enlarging aggregate demand" ( $A B$, June 27, 1974), while in the December 1975 quotation above Emminger stated the non-accommodation principle. Quarterly inflation peaked at end-1973 and annual inflation in 1974:Q1, well ahead of the peaks in other countries. For Germany, the peak reflected a one-time price-level jump from the OPEC shock, as well as pre-1973 monetary ease, and did not reflect accommodation of the oil shock. ${ }^{32}$

Second, while focusing on money growth, the authorities did not discard evidence from real variables; as noted above, in 1973, Bundesbank Director Schlesinger had described the new policy as "anticyclical," while the Bundesbank's annual reports in the 1970s and into the 1980s plotted estimates of potential output (e.g., $B B A R$, April 1981, 11). ${ }^{33}$ The attention to the output gap in policymaking did not contradict the reaffirmed orientation of monetary policy on inflation control. But it did raise the possibility that outputgap mismeasurement, occurring especially with the post-1973 economic slowdown, would provoke inappropriate monetary easings, as Orphanides (2003) argues occurred in the 1970s in the United States. The Bundesbank partially avoided this problem by promptly recognizing some of the post-1973 slowdown. Emminger said in 1975 that policymakers "definitely" expected permanently lower economic growth because of slower growth in the labor force and other structural changes ( $T G$, March 5, 1975), as well as "a somewhat higher level of unemployment than we have been used to since the 1960s" ( $C A P$, February 1975, a.t.).

\footnotetext{
${ }^{31}$ Tactical features of the regime, i.e., the operating procedures used by the Bundesbank in the financial markets, are not discussed here due to my focus on strategy. Bernanke et al. (1999), Issing (1997), and von Hagen (1999a) provide extensive discussions of Bundesbank operating procedures.

${ }^{32}$ Therefore, the suggestion by Clarida and Gertler $(1997,375)$ that the Bundesbank heavily accommodated the first oil shock does not seem to be warranted.

${ }^{33}$ Von Hagen $(1999 b, 434)$ and Gerberding, Seitz, and Worms (2005) also indicate that countercyclical considerations weighed heavily in the Bundesbank's internal deliberations.
} 
Third, German policymakers, like their Japanese counterparts, had "speed-limit" concerns about inflationary pressure. For example, in December 1975 Emminger observed that "an economy may run into bottlenecks long before reaching full employment" (AUP, December 19, 1975, 3), a position he reaffirmed in 1978 (AUP, February 3, 1978). Consistent with this concern, Bundesbank Director Schlesinger gave "current utilization of the production potential, and possible changes in this utilization" as factors that affected the choice of each year's money-growth target (AUP, October 11, 1977, 3). Of these, the change in utilization evidently came to have the more systematic effect on policy decisions, at least after 1978: for the twenty years beginning in 1979:Q1, Gerberding, Seitz, and Worms (2005) find that responses to the output gap in the Bundesbank's policy rule are small and statistically insignificant, while responses to output-gap growth are significant. Mismeasurement of the level of the output gap was substantial in Germany in the second half of the 1970s, as they show, so the basing of policy on output-gap growth was beneficial. The official statements cited above on the link between bottlenecks and inflation suggest that the Bundesbank's focus on output-gap growth did not arise from skepticism about the level estimates but from belief in a speed-limit term (in addition to a gap-level term) in the Phillips curve. ${ }^{34}$

Fourth, incomes policy did not play a part in the disinflation. As discussed in the introduction, advocates of incomes policy outside Germany attributed German inflation success to union-government cooperation regarding nominal-wage growth. Such accounts have no merit. The consultation body, Concerted Action, which had been cited as an anti-inflationary tool during the heyday of cost-push views in Germany, was disbanded in $1977 .{ }^{35}$ A Bundesbank official explained in 1980 that the authorities "gave up" on Concerted Action, adding, "I do not think that we or the trade unions felt that this was a very important arrangement as far as actual

\footnotetext{
${ }^{34}$ Equally, by seeming to explain the short-run coexistence of negative output gaps and inflation, the speed-limit perspective on Phillips-curve dynamics probably slowed down German policymakers' revision of their output-gap estimates to more accurate values.

${ }^{35}$ Braun (1986, 240).
} 
policymaking is concerned" (Dudler 1980, 305). On the more general question of incomes policies, the Bundesbank stated: "The Bundesbank and Federal Government have never regarded administrative wage and price controls as an alternative (or supplement) to monetary policy.... The Government neither intervenes directly in specific wage and price decisions nor attempts to hold trade unions or employers' associations to formal wage and price guidelines.... $[\mathrm{T}]$ here is practically no convincing evidence of the lasting success of any variant of direct income[s] policy" (Deutsche Bundesbank 1980, 295). ${ }^{36}$

Fifth, the Bundesbank did concede an influence of cost-push pressures on inflation in their published estimates of the amount of "unavoidable" inflation in the year ahead, i.e., the Bundesbank's "price assumption" or inflation target. This concept encompassed not only the inflationary pressure built in by prior monetary policy decisions but also price-level shocks that were conceded as having an impact effect on inflation. A Bundesbank official in 1980 gave "higher raw material prices or oil prices" as influences on the unavoidable inflation rate (Dudler 1980, 299). The impact of such factors on inflation is, however, compatible with the monetary view of inflation, since according to that view, it is expected future inflation, not current inflation, that is pinned down by monetary policy alone. In addition, the announced price assumption tended to decline, settling at a rate of 2 percent after $1985,{ }^{37}$ showing that even the "unavoidable" component of inflation was regarded as an endogenous variable at horizons beyond the short run.

It is likely, however, that the Bundesbank overestimated the importance of cost-push factors in the determination of unavoidable inflation. For example, in 1978 the Bundesbank believed, in the words of one official, that the mark was "faced with the prospect of an uncontrolled appreciation" (Dudler 1980, 306), and undertook

\footnotetext{
${ }^{36}$ Similarly, a description by Germany's federal government of economic policy said, "[W]age freezes or the fixing or limiting of wage increases are not included amongst the instruments employed in evolving the State's economic policy" (quoted in UKPD, November 9, 1978, p. 1218).

${ }^{37}$ See Coenen, Levin, and Christoffel (forthcoming) and Gerberding, Seitz, and Worms (2005).
} 
unsterilized intervention to offset some of the upward pressure. ${ }^{38}$ This was despite the fact that over this period, President Emminger gave "one to three percent" as the only inflation rate that the Bundesbank considered tolerable ( $B K R$, September 1978). It is clear that the Bundesbank thought it could get away with monetary stimulus in 1978 despite its monetary view of inflation because it believed that the negative impact effect on inflation from mark appreciation would offset the upward pressure coming from the monetary easing. In 1980 a Bundesbank official was very open about this, revealing that the authorities had "felt that pursuing a low interest-rate policy and allowing monetary growth to accelerate would not have a detrimental effect" on inflation (Dudler 1980, 306-7). This proved not to be the case, as annual CPI inflation exceeded 5 percent in 1980, a rate above what the Bundesbank regarded as acceptable even in the face of the second oil shock. ${ }^{39}$ An alternative policy in 1978, which disregarded the nonmonetary influences on inflation, would have led to this error being avoided. The misjudgments underlying the 1978 episode probably played a part in leading Karl-Otto Pöhl, who became Bundesbank president in 1980, to state, "Interest rates should be set according to domestic monetary conditions and the exchange rate should be left to go where it will." 40

\section{Did Policymakers Try to Exploit a Phillips-Curve Trade-Off?}

The preceding sections drew attention to some lessons regarding 1970s policymaking in Japan and Germany. In particular, both countries switched from a problematic nonmonetary approach to inflation control in 1971-72 to a monetary approach to inflation control in 1973; confidence in monetary policy was reinforced by falling inflation in 1975; and the particular variables policymakers used to measure excess demand - namely, money growth and the change in the output gap - enhanced preemptiveness of policy and reduced

\footnotetext{
${ }^{38}$ See von Hagen $(1999 a, 693)$ for other details of this episode based on different sources.

39 "We certainly would feel that a rate of $5 \%$ is too high ... for what we might accept as an unavoidable structural built-in inflation element" (Dudler 1980, 301).

${ }^{40}$ Quoted in Thatcher $(1995,479)$.
} 
the influence of estimated output-gap levels on policymaking. I now consider a further lesson about policymaking and inflation behavior that emerges from joint study of the two countries.

An important element of many accounts of the United States' Great Inflation, including those of DeLong (1997) and Sargent (1999), is the position that policymakers were guided by the view that there was a long-run, exploitable Phillips-curve trade-off between inflation and unemployment. The evidence in this paper casts serious doubt on this story as an explanation for the Great Inflation that is valid across countries. Belief in Phillips-curve tradeoffs simply was not an important factor behind policy mistakes in Germany and Japan.

A belief in a long-run Phillips-curve trade-off was not the source of Germany's 1970s inflation problems. The essentials of the long-run vertical-Phillips-curve view had been voiced officially in Germany in 1970, by Finance Minister Schiller, who shared his predecessors' goal of price stability. ${ }^{41}$ Moreover, in 1975 Bundesbank President Klasen said it was "wrong" to believe in "a long-lasting solution to unemployment through more inflation" ( $N W$, February 17, 1975). Where policymakers - notably Schiller and Klasen-lapsed in the 1970s, it was in succumbing to cost-push views, not trade-off pursuits.

Their lapse also indicates that denying a long-run Phillips-curve trade-off is not enough. A sound official doctrine also needs to be subtle by taking care not to reject all aspects of Phillips-curve analysis. From the perspective of modern macroeconomics, the phenomenon of stagflation reflects the impact on inflation dynamics of two terms that appear in a correctly specified Phillips curve: expected inflation and shocks to potential output. But 1970s policymakers could be - and indeed were, especially outside Germany - tempted to interpret stagflation as instead revealing that no relationship existed between unemployment (and so the output gap) and inflation, or that the relationship was positive under all circumstances. Such misinterpretations, while successful in leading policymakers away from attempts to exploit trade-offs, are unhelpful because they obscure the fact that the way to remove inflation is to work

\footnotetext{
${ }^{41}$ As former Chancellor Erhard put it, "I am convinced the maximum rate of price increases should be 2 percent-but 1 percent is preferable. Herr Schiller wants that, too" (quoted in $K C S$, July 1, 1970).
} 
through the aggregate-demand channel. It is not, therefore, a badge of honor to be so hawkish about inflation as to believe that inflation has only a positive relationship with unemployment. This variant of hawkishness obscures the mechanisms connecting monetary policy actions to inflation, so it is not really a road to a low-inflation regime.

In this light, a notable contribution by Helmut Schmidt to German economic policymaking, in addition to transferring inflation control to monetary policy, was to restore a balanced view of the unemployment/inflation relationship. Schmidt voiced a subtle interpretation, stating that the message of the data was "that the correlation between unemployment and inflation is different, but that there is a fundamental connection" (DZ, November 8, 1974, a.t.), and that it was "too simple to say that inflation causes unemployment" (SZ, June 24, 1975, a.t.). Similarly, Helmut Schlesinger of the Bundesbank noted that raising economic growth and cutting inflation were not compatible in the short run, because "to reduce inflation means dampening the economy" (CT, October 22, 1981). These calls for subtlety are in harmony with the attitude of Milton Friedman, who wrote in 1979: "Orthodox wisdom has it that unemployment is a cure for inflation. A minority has it that unemployment causes inflation. Both views are half-truths" ( $N W$, November 12 , 1979).

In Japan, there was no point where belief in a long-run trade-off was the official view. In February 1970, Finance Minister Fukuda gave Japan's unavoidable inflation rate as $4-5$ percent (JT, February 20, 1970), with the government stating that "to maintain our economic growth, some degree of price increase is inevitable" (JT, March 3, 1970). This claim was not, however, based on a Phillipscurve trade-off calculation; the Phillips-curve trade-off implies that higher inflation can buy a higher level of output, whereas the government's statement referred to the inevitability that moderate inflation would coexist with steady-state economic growth.

It is likely that the Japanese government was not simply stating that reducing inflation below 4 percent would require a temporary disruption of growth. Rather, its references to 4-5 percent inflation as unavoidable or inevitable probably indicated a view that superneutrality violations (e.g., "wheel-greasing" effects of inflation) existed that made $4-5$ percent inflation rates (approximately 
the rates observed during the 1960s) conducive to continuation of Japan's 1960s economic growth. ${ }^{42}$ Certainly higher inflation rates were ruled out: even in 1970, the government regarded bringing inflation back below 5 percent as a desirable immediate goal and reducing it to 3-4 percent as a long-term goal (JT, February 20, 1970; March 3, 1970). The subsequent 20-point rise in Japan's inflation rate cannot plausibly be attributed to government exploitation of a trade-off calculation: as noted, the government wanted to bring inflation back below 5 percent, while in 1971-72 it had nonmonetary (and therefore non-Phillips-curve) views of the inflation process. After 1973, Japanese policymakers indicated that they viewed inflation dynamics in terms of a conventional, long-run vertical Phillips curve. $^{43}$

\section{Conclusion}

Many theories about why countries inflate take for granted that policymakers understand that inflation is a monetary phenomenon. The evidence presented in this paper suggests that these theories do not have merit in understanding Germany's and Japan's 1970s experiences. Two particular factors often cited as important in accounting for inflation outcomes-(i) government pressure on central banks to inflate and (ii) policymakers' belief in a long-run unemployment/inflation trade-off - do not appear important in understanding these countries' inflation-disinflation pattern. The suggestion that central bank independence is an important factor in delivering low inflation is belied by these countries' experiences. Japan's central bank was not independent, yet Japan disinflated early; and in Germany's case, pressure for disinflation came from Finance Minister Helmut Schmidt who, despite the Bundesbank's official

\footnotetext{
${ }^{42}$ For example, an empirical regularity of the 1960s was that Japan's wholesale price index was stable even as the CPI rose (Komiya and Suzuki 1977, 306). It may have been thought that the resulting relative-price pattern was one condition for Japan's steady-state growth and might be disturbed if CPI inflation proceeded at zero or very low rates.

${ }^{43}$ The particular favored variant of the Phillips curve in policy circles was one with stickiness in prices and flexibility in nominal wages (see, e.g., Suzuki 1985). Ball (1994, 174) and Taylor (1989, 137-42) likewise suggest that nominal-wage flexibility may be a reasonable approximation for Japan.
} 
independence, played a major role in retrieving order in monetary arrangements after the shambles of the 1971-72 period. The argument that policymakers' belief in a long-run Phillips-curve trade-off, and subsequent acceptance of no long-run trade-off, drove monetary policy developments is also not supported for either country.

What appears necessary for a successful explanation for the Great Inflation across countries is an account that does not take for granted policymakers' understanding of the monetary character of inflation. The monetary-policy-neglect hypothesis suggests that high-inflation episodes in the 1970s reflect neither conscious acceptance of inflationary policies by governments nor denial by policymakers of the costs of inflation. The analysis of Germany and Japan in this paper suggests that this hypothesis is useful for understanding their early embrace of disinflation. Germany's and Japan's experiences in the 1970s indicate that once inflation is accepted by policymakers as a monetary phenomenon, the main obstacle to price stability has been overcome.

\section{Appendix 1. Abbreviations for Periodicals Cited in Text}

AB-American Banker (United States)

AUP-Auszüge aus Presseartikeln (Deutsche Bundesbank, Frankfurt)

AZR-Arizona Republic (Phoenix, AZ)

$B B A R$-Report of the Deutsche Bundesbank (Annual Report) (Frankfurt)

$B K R$ - The Banker (London)

$C A P$ - Capital (Germany)

CT-Chicago Tribune (Chicago, IL)

DS-Der Spiegel (Hamburg)

DT-Daily Telegraph (London)

$D W$-Die Welt (Hamburg)

DZ-Die Zeit (Hamburg)

FAZ-Frankfurter Allgemeine Zeitung (Frankfurt am Main)

FT-Financial Times (London)

IP-Irish Press (Dublin)

JC-Journal of Commerce (Newark, NJ)

JT-Japan Times (Tokyo)

KCS-Kansas City Star (Kansas City, MO) 
KYO-Kyodo News Service (Tokyo)

NKS-Nihon Keizai Shimbun (Tokyo)

$N W$-Newsweek (United States and Europe)

NYT-New York Times (New York)

SCMP_South China Morning Post (Hong Kong)

STR-Straits Times (Singapore)

SUN-The Sun (London)

SZ-Süddeutsche Zeitung (Munich)

TE-The Economist (London)

$T G$ - The Guardian (London and Manchester)

UKPD-U.K. Parliamentary Debates: House of Commons (London)

WSJ-Wall Street Journal (New York)

\section{Appendix 2. Chronological List of Periodical Articles Cited on Great Inflation in Japan and Germany}

Japan

Auszüge aus Presseartikeln, "Ansprache des japanischen Finanzministers Takeo Fukuda," (excerpts from speech at World Bank, September 30, 1969) October 7, 1969, pp. 12-13.

Japan Times, "Text of Sato's Policy Speech," December 2, 1969, p. 12.

Editorial. "Nikkeiren's Wage Proposal." Japan Times, February 1, 1970, p. 12.

Japan Times, "Fukuda Says 4-5\% Rise in Prices Inevitable," February 20, 1970, pp. 1 and 5.

Editorial. "Your Yen's Worth." Japan Times, March 3, 1970, p. 12. Porter, S. "Japanese Worker Saving-est in World." Arizona Republic, May 13, 1970, p. F8.

Kyodo News Service. "Incomes Policy Gets Debated at Seminar." Japan Times, July 10, 1970, p. 10.

Japan Times, "Bank of Japan Reduces Official Discount Rate by 0.25\% to 6\%: Policy Body Thinks Tight Money Has Achieved Purpose," October 28, 1970, pp. 1 and 5.

Japan Times, "Consumer Prices Rising: EPA Warns Against Large Wage Hikes," December 5, 1970, p. 13. 
Japan Times, "Government Freezes Most Public Charges for Indefinite Period," December 10, 1970, pp. 1 and 5.

South China Morning Post, "Japan May Adopt 'Incomes' Policy," December 12, 1970, Business News, p. I.

Japan Times, "Revaluation of Yen Dismissed by Sasaki," March 11, 1971, p. 14.

Editorial. "An Economy in Transition." Japan Times, January 4, 1972, p. 14.

Editorial. "The Fiscal 1972 Budget." Japan Times, January 14, 1972, p. 14.

Hara, S. "World Economy Sluggish But Prospects Improving; Nixon's Plan, Surtax, Revaluation Hit Japan Hard." Japan Times, May 31, 1972, p. 11.

Japan Times, "Credit Squeeze Likely in Bid to Curb Inflation," December 25, 1972, p. 12.

Japan Times, "Economy Overheated, Bank of Japan Says," February 8, 1973, p. 11.

Nihon Keizai Shimbun, "Tight Money Policy," April 11, 1973 (translation in Japan Times, April 12, 1973, p. 14).

Japan Times, "Govt. Plans to Expand Import Quotas by $30 \%$ Over Levels for 1972," April 14, 1973, pp. 1 and 5.

Japan Times, "Govt. Ministers Agree on Need to Stabilize Prices," May 26, 1973, p. 1.

Japan Times, "Tight Money Steps Viewed Skeptically," Japan Times, May 30, 1973, p. 10.

Editorial. "Discount Rate Raise." Nihon Keizai Shimbun, May 30, 1973 (translation in Japan Times, May 31, 1973, p. 14).

Japan Times, "Premier Feels Govt. Tight Money Policy Will Curb Inflation," July 6, 1973, pp. 1 and 5.

Japan Times, "Tight Money Policy to Continue: Premier," November 2, 1973, p. 12 .

Japan Times, "Premier Rules Out Need for Incomes Policy," December 9, 1973, pp. 1 and 3 .

Japan Times, "Govt. Forecasts GNP Rise of $2.5 \%$ for 1974, Lowest in 20 Years," December 22, $1973 a$, pp. 1 and 3.

Japan Times, "Bank Rate Raised by 2\% to Reach Record 9\%," December 22, 1973b, p. 1.

Editorial. "Changed Economic Fortunes." Japan Times, December 30, 1973, p. 8. 
The Economist, "Japanese Budget: Austerity, Gift-Wrapped," January 5, 1974, p. 72.

Japan Times, "Tanaka Requests Labor to Show Restraint in New Wage Raise Bid," February 22, 1974, pp. 1 and 4.

Japan Times, "Japan Will Slow Down Growth Rate: Fukuda," May 10, 1974, p. 8.

Halloran, R. "Japan's Economy in a Deep Slump," New York Times, June 12, 1974, pp. 61 and 67.

Japan Times, "Noted Economist Says: Wage Increases Will Help Push Up Prices," June 21, 1974, p. 9.

Japan Times, "Ohira Pledges Efforts to Gain Price Stability," August 3, 1974, p. 1.

South China Morning Post, "Japan Plans Controls to Fight Price Rises," October 8, 1974, p. B2.

Japan Times, "15\% 'Limit' to Price Increases Agreed On," October 12,1974, p. 1 .

Editorial. "Priority to Inflation Fight." Japan Times, October 23, 1974, p. 12.

Japan Times, "Tight Govt. Budget for 1975 Foreseen," October 29, 1974, p. 9.

Japan Times, "Fukuda Urges Labor to Help End Inflation," December 19, 1974, p. 8.

Japan Times, "Govt. Will Keep Tight Money Policy: Fukuda," January 18, 1975, p. 9.

Japan Times, "Prime Minister Miki's Policy Speech," January 25, 1975 , p. 12.

Wilson, S. "Anti-Inflation Drive Slowing Down Japan's Price Hikes," Straits Times, January 29, 1975.

Nihon Keizai Shimbun, "Discount Rate Cut," April 16, 1975 (translated in Japan Times, April 17, 1975, p. 12).

Koshiba, K. "Business Pressing for Bigger Cut." Japan Times, April 21, 1975, p. 11.

Yokoyama, S. "Inflation, Growth Slow Up as 1973 Policies Take Hold." Japan Times, May 31, 1975, p. 10.

Japan Times, "Another Bank Rate Cut Urged by Fukuda," June 9, 1975, p. 9.

Japan Times, "Must Beat Inflation in Order to Cure Economy: White Paper," August 9, 1975, p. 1. 
Editorial. "Recovery Without Inflation." Japan Times, August 14, 1975, p. 12.

Reuter. "Japan Pulling Out of Serious Recession, Reports Govt. Agency." Straits Times, August 19, 1975, p. 11.

Japan Times, "Tokyo Inflation Rate Finally Brought Down to Single Digit," November 29, 1975, p. 1.

Koshiba, K. "Prices Slowdown Triumph for Fukuda." Japan Times, March 29, 1976, p. 5.

Editorial. "A Mini-Recovery Program." Japan Times, November 15, 1976, p. 12.

Japan Times, "January CPI Jumps by 1.1\%; Imperils Anti-Inflation Goal," January 29, 1977, p. 1.

Editorial. "Recovery with Less Inflation." Japan Times, April 28, 1977, p. 12.

Japan Times, "Nationwide Consumer Price Increase Hit 9.4\% for 1976," April 29, 1977, p. 1.

Editorial. "The New Reflation Program." Japan Times, September 8, 1977, p. 16.

Japan Times, "Ohira Pushes for 7\% Growth Rate in Debate," January 22,1978 , p. 3.

Japan Times, "Bank of Japan Lowers Official Discount Rate to Record 3.5\%," March 16, 1978, p. 1.

Japan Times, "Bank Interest, at 5.9\%, Lowest Since WWII," June 23, 1978, p. 5.

Editorial. "Prices, Yen, and Consumers." Japan Times, July 26, 1978, p. 12.

Friedman, M. "Japan and Inflation." Newsweek (U.S. edition), September 4, 1978, p. 75.

Takahashi, T. "High-Growth Structure of the Past Must Be Changed to Solve Problems." Japan Times, October 6, 1978, p. 5.

Koshiba, K. "Economy Scarred by Oil, Yen Shocks," Japan Times, October 16, 1978, p. 4.

Associated Press. "Bank of Japan Chief Asks Curb on Money Supply." New York Times, December 28, 1978, p. D3.

Editorial. "A Fitting Reply to Inflation Threat." Japan Times, April 18, 1979, p. 12.

Kyodo News Service. "Credit Policy Unlikely to Affect Inflation." Wire commentary, May 23, 1979 (reprinted by U.S. 
government in Joint Publications Research Service: 073754, pp. 33-35).

Ministry of Foreign Affairs. "Japan's Economy - Current Status and Future Prospects." Official government bulletin, in Japan Times, June 26, 1979, p. 9.

Japan Times, "BoJ to Up Official Bank Rate to 7.25\%," February 19, 1980, pp. 1 and 3 .

\section{Germany}

Japan Times, "Reserve Requirements Raised in W. Germany," June 20, 1970, p. 11.

Weber, S. "Inflation (Only 4\%) Upsets Germans." Kansas City Star, July 1, 1970, p. 2D.

Wall Street Journal Staff Reporter. "West Germany Cuts Borrowing Rate to 7\% for Commercial Banks," Wall Street Journal, July 16, 1970, p. 4.

Der Spiegel, "Spiegel-Interview mit Dr. Otmar Emminger, Vizepräsident der Deutschen Bundesbank," July 20, 1970 (reprinted in Auszüge aus Presseartikeln, July 22, 1970, pp. 6-7). Schiller, K. "Ansprache des Bundeswirtschaftsministers Professor Karl Schiller." September 21, 1970, Speech, World Bank, in Auszüge aus Presseartikeln, September 24, 1970, pp. 8-9.

Mauthner, R. "Need to Combat Inflation." Financial Times, January 1, 1971, p. 15.

Herlt, R. "Lohn- und Preisforderungen gefährden Stabilität der Mark: Interview mit Bundesbankpräsident Klasen." Die Welt, January 23, 1971, pp. 1-2 (reprinted in Auszüge aus Presseartikeln, January 26, 1971, pp. 1-2).

Klasen, K. "Remarks on Our Common Efforts to Curb Inflation." Speech, German-American Chamber of Commerce, New York, January 27, 1971, in Auszüge aus Presseartikeln, February 2, 1971, pp. 2-4.

Irish Press, "W. Germany Not to Cut Bank Rate," March 18, 1971, p. 12.

Editorial. "Kosteninflation." Frankfurter Allgemeine Zeitung, March 18, 1971, p. 1. 
Richards, J. "When Wages Go Boom! West Germany's Conscientious Search for an Incomes Policy." Daily Telegraph, April 1, 1971, p. 11.

Herlt, R. "Keine Recession-Nur Abbau der Überbeschäftigung: Interview mit Bundesminister Schiller über Preise, Löhne, Arbeitsplätze, Europa und die Währung." Die Welt, June 23, 1971, p. 7 (reprinted in Auszüge aus Presseartikeln, June 24, 1971, pp. 1-3).

Schiller, K. "Ansprache des Bundesministers für Wirtschaft und Finanzen Professor Karl Schille." Speech to the IMF and World Bank, Washington, DC, September 30, 1971, in Auszüge aus Presseartikeln, October 5, 1971, pp. 3-5.

Deutsche Bundesbank. Report of the Deutsche Bundesbank for the Year 1971, April 1972.

van Voorst, B. “'We're a Pillar of Free Trade': Interview with Helmut Schmidt." Newsweek (European edition), August 21, 1972.

Japan Times, "In Bid to Fight Inflation, W. Germany Hikes Bank Rate to 3.5\%," October 8, 1972, p. 11.

Süddeutsche Zeitung, "Die Wirtschafts- und Finanzpolitik der nächsten vier Jahre," Interview with Finance Minister Helmut Schmidt, December 21, 1972 (reprinted in Auszüge aus Presseartikeln, January 2, 1973, pp. 7-9).

Deutsche Bundesbank. Report of the Deutsche Bundesbank for the Year 1972, April 1973.

Japan Times, "To Check Steep Price Rise, W. Germany Raises Bank Rate to 6\%," May 5, 1973, p. 11.

South China Morning Post, "Far-Reaching Measures to Curb Inflation," May 11, 1973, p. VI.

The Economist, "Freeze Not Squeeze," June 9, 1973, pp. 75-76.

United Press International. "Erhard Urges Steps to Curb Inflation." Japan Times, June 22, 1973, p. 11.

Schlesinger, H. "Role of the Bundesbank." Financial Times, October 8, 1973, West Germany special section, p. IV.

Lukomski, J. M. "Bundesbank's Restrictive Credit Policy Under Fire from Dresdner Bank Official." Journal of Commerce, November $5,1973$.

Emminger, O. "Probleme der Stabilitätspolitik." Speech, Frankfurt, November 9, 1973, in Auszüge aus Presseartikeln, November 9, 1973, pp. 4-7. 
Editorial. "What's the German for Stagflation?" The Economist, November 10, 1973, pp. 92-93.

United Press International. "Chancellor Brandt Says Wage, Price Freeze Not Planned by Bonn." Japan Times, February 3, 1974, p. 8.

Klasen, K. "Inflation Fight Requires Money, Credit Restraint." American Banker, International Banker section, June 27, 1974, pp. $1 \mathrm{~A}$ and $8 \mathrm{~A}$.

Stolze, D., and R. Zundel. "Neuer Aufschwung für die Wirtschaft: Zeit-Interview mit Bundeskanzler Helmut Schmidt." Die Zeit, November 8, 1974, pp. 3-4 (reprinted in Auszüge aus Presseartikeln, November 12, 1974, pp. 2-4).

Capital, "Erster Lichtblick: Bundesbankier Emminger uber die Aussichten der Wirtschaft," February 1975, pp. 8-9.

Newsweek (European edition), "There Won't Be a Global Recession'," Interview with Bundesbank President Klasen, February $17,1975$.

Cairncross, Frances. "Keeping Inflation under Control." (Manchester edition title: "Recovery in Spite of Inflation.") The Guardian, March 5, 1975, p. 17.

Deutsche Bundesbank. Report of the Deutsche Bundesbank for the Year 1974, April 1975.

Süddeutsche Zeitung, "Interview der Süddeutsche Zeitung mit Bundeskanzler Schmidt," June 24, 1975 (reprinted in Auszüge aus Presseartikeln, July 1, 1975, pp. 1-3).

Emminger, O. "The Role of the Central Banker." Remarks at World Banking Conference, London, December 10, 1975, in Auszüge aus Presseartikeln, December 19, 1975, pp. 1-5.

Carroll, R. "Do We Really Need Another Year of Pay Curbs?" The Sun, March 9, 1977, pp. 16-17.

Schlesinger, H. "Problems of Monetary Policy in Germany: Some Basic Issues." Address at Wiesbaden, September 29, 1977, in Auszüge aus Presseartikeln, October 11, 1977, pp. $1-5$.

Emminger, O. "Aktuelle Fragen der Geld- und Währungspolitik." Address at Wiesbaden, January 31, 1978, in Auszüge aus Presseartikeln, February 3, 1978, pp. 1-5.

The Banker, "Interview: Dr. Otmar Emminger," September 1978, pp. 20-23. 
Howe, G. Speech in the House of Commons (with quotation from a German federal government statement), in U.K. Parliamentary Debates (House of Commons), November 9, 1978, pp. 1211-28.

Friedman, M. "Inflation and Jobs." Newsweek (U.S. edition), November 12, 1979, p. 97.

Deutsche Bundesbank. Report of the Deutsche Bundesbank for the Year 1980, April 1981.

Longworth, R. C. "Inflation Climb Feared: Europe Sees Reaganomics Fall." Chicago Tribune, October 22, 1981, pp. B1 and B3.

\section{References}

Ball, L. 1994. "What Determines the Sacrifice Ratio?" In Monetary Policy, ed. N. G. Mankiw, 155-88. Chicago: University of Chicago Press.

Bernanke, B. S., T. Laubach, F. S. Mishkin, and A. S. Posen. 1999. Inflation Targeting: Lessons from the International Experience. Princeton, NJ: Princeton University Press.

Bernanke, B. S., and I. Mihov. 1997. "What Does the Bundesbank Target?" European Economic Review 41 (6): 1025-53.

Braun, A. R. 1986. Wage Determination and Incomes Policy in Open Economies. Washington, DC: International Monetary Fund.

Brown, A. J., and J. Darby. 1985. World Inflation Since 1950: An International Comparative Study. Cambridge, UK: Cambridge University Press.

Burns, A. F. 1978. Reflections of an Economic Policy Maker: Speeches and Congressional Statements: 1969-1978. United Kingdom: Rowman and Littlefield.

Clarida, R., J. Galí, and M. Gertler. 1999. "The Science of Monetary Policy: A New Keynesian Perspective." Journal of Economic Literature 37 (4): 1661-1707.

Clarida, R., and M. Gertler. 1997. "How the Bundesbank Conducts Monetary Policy." In Reducing Inflation: Motivation and Strategy, ed. C. D. Romer and D. H. Romer, 363-406. Chicago: University of Chicago Press. 
Coenen, G., A. T. Levin, and K. Christoffel. Forthcoming. "Identifying the Influences of Nominal and Real Rigidities in Aggregate Price-Setting Behavior." Journal of Monetary Economics.

Committee on Banking, Housing, and Urban Affairs. 1977. First Meeting on the Conduct of Monetary Policy. Washington, DC: U.S. Government Printing Office.

Culbertson, J. M. 1960. "Friedman on the Lag in Effect of Monetary Policy." Journal of Political Economy 68 (6): 617-21.

DeLong, J. B. 1997. "America's Peacetime Inflation: The 1970s." In Reducing Inflation: Motivation and Strategy, ed. C. D. Romer and D. H. Romer, 247-76. Chicago: University of Chicago Press.

Deutsche Bundesbank. 1980. "Control of the Money Supply in the Federal Republic of Germany." Memorandum, June 25, 1980, in Treasury and Civil Service Committee, Monetary Policy Volume II: Minutes of Evidence, 290-97. London: HMSO, 1981.

Dudler, H.-J. 1980. "Examination of Witnesses: Hermann-Josef Dudler." Testimony, November 10, 1980, in Treasury and Civil Service Committee, Monetary Policy Volume II: Minutes of Evidence, 297-307. London: HMSO, 1981.

Emminger, O. 1977. The D-Mark in the Conflict Between Internal and External Equilibrium, 1948-75. Princeton University Essays in International Finance No. 122.

Fels, G. 1977. "Inflation in Germany." In Worldwide Inflation: Theory and Recent Experience, ed. L. B. Krause and W. S. Salant, 589-622. Washington, DC: Brookings Institute.

Friedman, M. 1983. "Monetarism in Rhetoric and in Practice." Bank of Japan Monetary and Economic Studies 1 (2): 1-14.

- 1990. Friedman in China. Hong Kong: Chinese University Press.

Gerberding, C., F. Seitz, and A. Worms. 2005. "How the Bundesbank Really Conducted Monetary Policy." North American Journal of Economics and Finance 16 (3): 277-92.

Giannoni, M. P. 2002. "Does Model Uncertainty Justify Caution? Robust Optimal Monetary Policy in a Forward-Looking Model." Macroeconomic Dynamics 6 (1): 111-44.

Hamada, K. 1985. "Lessons from the Macroeconomic Performance of the Japanese Economy." In Inflation and Unemployment: Theory, Experience and Policy-Making, ed. V. E. Argy and J. W. Nevile, 181-99. London: Allen and Unwin. 
Hetzel, R. L. 1999. "Japanese Monetary Policy: A Quantity Theory Perspective." Economic Quarterly (Federal Reserve Bank of Richmond) 85 (1): 1-25.

Hillenbrand, M. J. 1983. Germany in an Era of Transition. Paris: Atlantic Institute for International Affairs.

Humphrey, T. M. 1985. "The Early History of the Phillips Curve." Economic Review (Federal Reserve Bank of Richmond) 71 (5): $17-24$.

Issing, O. 1997. "Monetary Targeting in Germany: The Stability of Monetary Policy and of the Monetary System." Journal of Monetary Economics 39 (1): 67-79.

- 2005. "Why Did the Great Inflation Not Happen in Germany?" Review (Federal Reserve Bank of St. Louis) 87 (2): $329-35$.

Komiya, R., and Y. Suzuki. 1977. "Inflation in Japan." In Worldwide Inflation: Theory and Recent Experience, ed. L. B. Krause and W. S. Salant, 303-48. Washington, DC: Brookings Institute.

Laidler, D. 1978. "Review: Towards Full Employment and Price Stability." Journal of Economic Literature 16 (3): 1040-44.

McCracken, P., G. Carli, H. Girsch, A. Karaosmanoglu, R. Komiya, A. Lindbeck, R. Marjolin, and R. Matthews. 1977. Towards Full Employment and Price Stability. Paris: OECD.

Nelson, E. 2005. "The Great Inflation of the Seventies: What Really Happened?" Advances in Macroeconomics 5 (1): Article 3.

Organization for Economic Co-operation and Development. 1973. The Measurement of Domestic Cyclical Fluctuations. Paris: OECD.

Orphanides, A. 2003. "The Quest for Prosperity without Inflation." Journal of Monetary Economics 50 (3): 633-63.

Orphanides, A., and J. C. Williams. 2006. "Inflation Targeting under Imperfect Knowledge." Working Paper No. 2006-14, Federal Reserve Bank of San Francisco.

Rasche, R. H. 1990. "Equilibrium Income and Interest Elasticities of the Demand for M1 in Japan." Bank of Japan Monetary and Economic Studies 8 (2): 31-58.

Romer, C. D. 2005. "Commentary: Origins of the Great Inflation." Review (Federal Reserve Bank of St. Louis) 87 (2): 177-85.

Romer, C. D., and D. H. Romer. 2002. "The Evolution of Economic Understanding and Postwar Stabilization Policy." In Rethinking 
Stabilization Policy, 11-78. Kansas City, MO: Federal Reserve Bank of Kansas City.

Sargent, T. J. 1999. The Conquest of American Inflation. Princeton,

NJ: Princeton University Press.

Suzuki, Y. 1981. "Why Is the Performance of the Japanese Economy

So Much Better?" Journal of Japanese Studies 7 (2): 403-13.

- 1985. "Japan's Monetary Policy over the Past 10 Years." Bank of Japan Monetary and Economic Studies 3 (2): 1-9.

Taylor, J. B. 1989. "Differences in Economic Fluctuations in Japan and the United States: The Role of Nominal Rigidities." Journal of the Japanese and International Economies 3 (2): 127-44.

- 1993. "Price Stabilization in the 1990s: An Overview." In Price Stabilization in the 1990s: Domestic and International Policy Requirements, ed. K. Shigehara, 1-6. London: Macmillan.

Thatcher, M. 1995. The Path to Power. London: HarperCollins.

Ueda, K. 1993. "Japanese Monetary Policy from 1970 to 1990: Rules or Discretion?" In Price Stabilization in the 1990s: Domestic and International Policy Requirements, ed. K. Shigehara, 191-212. London: Macmillan.

U.S. Senate Budget Committee. 1979. First Concurrent Resolution on the Budget-Fiscal Year 1980. Washington, DC: U.S. Government Printing Office.

von Hagen, J. 1999a. "Money Growth Targeting by the Bundesbank." Journal of Monetary Economics 43 (3): 681-701.

_. 1999b. "A New Approach to Monetary Policy (1971-8)." In Fifty Years of the Deutsche Mark: Central Bank and the Currency in Germany Since 1948, ed. Deutsche Bundesbank, 403-38. Oxford: Oxford University Press.

Walsh, C. E. 2003. "Speed-Limit Policies: The Output Gap and Optimal Monetary Policy." American Economic Review 93 (1): $265-78$.

West, K. D. 1993. "An Aggregate Demand-Aggregate Supply Analysis of Japanese Monetary Policy, 1973-1990." In Japanese Monetary Policy, ed. K. J. Singleton, 161-88. Chicago: University of Chicago Press. 